\title{
Transport of Antarctic krill (Euphausia superba) across the Scotia Sea. Part I: Circulation and particle tracking simulations
}

\author{
Bettina A. Fach ${ }^{\mathrm{a}, 1, *}$, John M. Klinck ${ }^{\mathrm{b}}$ \\ ${ }^{\mathrm{a}}$ Woods Hole Oceanographic Institution, Mail Stop 25, 266 Woods Hole Rd, Woods Hole, MA 02543, USA \\ ${ }^{\mathrm{b}}$ Center for Coastal Physical Oceanography, Crittenton Hall, Old Dominion University, Norfolk, VA 23529, USA
}

Received 1 October 2004; received in revised form 23 September 2005; accepted 7 March 2006

Available online 8 June 2006

\begin{abstract}
The Harvard Ocean Prediction System (HOPS) is configured to simulate the circulation of the Scotia Sea and environs. This is part of a study designed to test the hypothesis that Antarctic krill (Euphausia superba) populations at South Georgia in the eastern Scotia Sea are sustained by import of individuals from upstream regions, such as the western Antarctic Peninsula. Comparison of the simulated circulation fields obtained from HOPS with observations showed good agreement. The surface circulation, particularly through the Drake Passage and across the Scotia Sea, matches observations, with its northeastward flow characterized by three high-speed fronts. Also, the Weddell Sea and the Brazil Current, and their associated transports match observations. In addition, mesoscale variability, an important component of the flow in this region, is found in the simulated circulation and the model is overall well suited to model krill transport. Drifter simulations conducted with HOPS showed that krill spawned in areas coinciding with known krill spawning sites along the west Antarctic Peninsula continental shelf can be entrained into the Southern Antarctic Circumpolar Current Front (SACCF). They are transported across the Scotia Sea to South Georgia in 10 months or less. Drifters originating on the continental shelf of the Weddell Sea can reach South Georgia as well; however, transport from this region averages about 20 months. Additional simulations show that such transport is sensitive to changes in wind stress and the location of the SACCF. The results of this study show that krill populations along the Antarctic Peninsula and the Weddell Sea are possible source populations that can provide krill to the South Georgia population. However, successful transport of krill to South Georgia is shown to depend on a multitude of factors, such as the location of the spawning area and timing of spawning, and variations in the location of the SACCF. Therefore, this study provides insight into which environmental factors control the successful transport of krill across the Scotia Sea and with it a better understanding of krill distribution in the region.
\end{abstract}

(C) 2006 Elsevier Ltd. All rights reserved.

\footnotetext{
${ }^{*}$ Corresponding author. Tel.: + 4947148311459 ; fax: +4947148311149 .

E-mail address: bfach@awi-bremerhaven.de (B.A. Fach).

${ }^{1}$ Now at: Alfred-Wegener-Institute for Polar and Marine Research, Am Handelshafen 12, D-27570 Bremerhaven, Germany.
}

\section{Introduction}

The Scotia Sea lies east of Drake Passage and is bound to the north, east, and south by the North Scotia Ridge, the South Sandwich Arc, and the South Scotia Ridge, respectively (Fig. 1A). The large-scale flow of the Scotia Sea is dominated by the northeastward flow of the Antarctic Circumpolar 

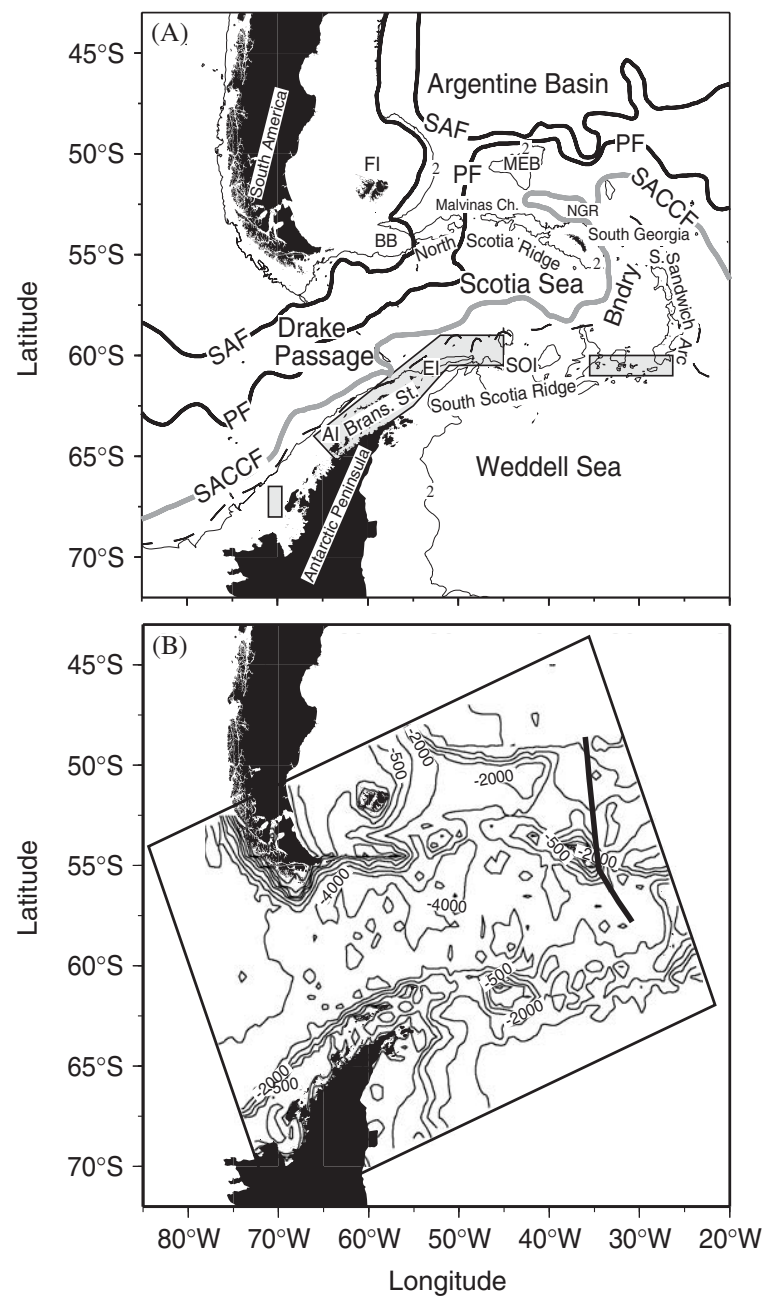

Fig. 1. (A) Base map showing the study region, the locations of the Subantarctic Front (SAF), the Polar Front (PF), the Southern Antarctic Circumpolar Current Front (SACCF), and the southern boundary of the Antarctic Circumpolar Current (dashed line; Bndry). The front locations were determined from historical hydrographic data given in Orsi et al. (1995). The thin line represents the 2000-m isobath. The areas of consistent Antarctic krill spawning, as identified in Marr (1962), are shown in gray. Geographic names are abbreviated as Falkland Islands (FI), Burdwood Bank (BB), Malvinas Chasm (Malvinas Ch.), Maurice Ewing Bank (MEB), North Georgia Rise (NGR), South Orkney Islands (SOI), Elephant Island (EI), Anvers Island (AI), and Bransfield Strait (Brans. St.). (B) Study area with the model domain indicated as a rotated rectangle. Contours are bottom topography in meters. Heavy line indicates the location of the WOCE A23 (near South Georgia) hydrography section used to validate circulation model results.

Current (ACC), in which high-speed frontal jets are embedded (Orsi et al., 1995). These bottomreaching fronts are, from north to south, the Subantarctic Front (SAF), Polar Front (PF), Southern Antarctic Circumpolar Current Front
(SACCF), and southern boundary of the ACC (Bndry). The SACCF is located close to the edge of the continental shelf (Orsi et al., 1995) and flows across the entire Scotia Sea (Fig. 1A).

The fronts of the ACC meander and lateral frontal shifts of as much as $100 \mathrm{~km}$ over 10 days have been observed (Hofmann and Whitworth, 1985; Nowlin and Klinck, 1986). In addition, studies have shown mesoscale variability associated with the flow on the continental shelf west of the Antarctic Peninsula (Stein, 1992), in Bransfield Strait (Niiler et al., 1991), and in Drake Passage (Joyce and Patterson, 1977; Peterson et al., 1982; Bryden, 1983; Hofmann and Whitworth, 1985; Klinck, 1985; Gille and Kelly, 1996; Moore et al., 1999). Frontal eddies found in the Drake Passage are usually observed to be $30-40 \mathrm{~km}$ in horizontal scale (Joyce and Patterson, 1977) and need an average time of 14 days to move through a region (Bryden and Pillsbury, 1977).

The Scotia Sea and environs are known to be one of the most biologically rich areas of the Southern Ocean and support a large standing stock of Antarctic krill, Euphausia superba (Marr, 1962). Many of the top predator populations that are part of the Antarctic marine food web, such as whales, seals, seabirds, penguins and fish, are dependent on krill as a food source (Fraser, 1936; Marr, 1962; Knox, 1970).

The waters around South Georgia (Fig. 1A) contain a persistent population of krill, which provides the primary food for many of the marine mammals, and seabirds that inhabit this region (Croxall et al., 1988). Early analyses of the length-frequency distribution of Antarctic krill populations around South Georgia led to the conclusion that the local population is not selfsustaining (Marr, 1962; Mackintosh, 1972). The apparent lack of a local population that undergoes reproduction with subsequent recruitment is surprising considering the large top predator populations that depend on Antarctic krill (Everson, 1984).

Because there is a persistent krill population at South Georgia in spite of no obvious local recruitment, the inference is that this is a sink population which depends on a source population elsewhere. It has been suggested that the Antarctic Peninsula is a source region for krill populations observed downstream in the Scotia Sea (Marr, 1962; Brinton, 1985; Siegel, 1992). Another potential krill source region is the Weddell Sea (Marr, 1962; Maslennikov and Solyankin, 1988; review by Atkinson et al., 2001). 
Transport of krill from these regions to South Georgia is thought to be accomplished by largescale ocean currents (Priddle et al., 1988; Witek et al., 1988; Murphy et al., 2004b).

However, direct observations that support krill transport from another region to South Georgia are few. Therefore, a modeling approach is used in this study to further the understanding of krill transport via ocean currents. Recently, the idea of krill transport to South Georgia from an upstream source was tested with modeling studies using a composite flow field (Hofmann et al., 1998; Murphy et al., 1998). These studies show that the currents associated with the ACC can transport particles from the Antarctic Peninsula to South Georgia in 140-160 days. The currents associated with the SACCF and Bndry, which flow along the outer continental shelf of the west Antarctic Peninsula, appear to be the primary transport pathways (Hofmann et al., 1998).

In this study a primitive equations circulation model with terrain-following coordinates, the Harvard Ocean Prediction System (HOPS), is implemented for the Scotia Sea and environs to simulate the current flow in this area and further investigate krill transport. The major scientific objective of this study is to investigate origination areas and transport pathways that can sustain recruitment for the Antarctic krill population around South Georgia, and how different spawning times affect the transport and survival of krill.

A primitive equation model was chosen to allow inclusion of the steep bottom topography that is present in the study region and to resolve rapid flow changes associated with fronts. The vertical model structure consists of level upper layers to support higher accuracy in the upper ocean and the main thermocline (Lozano et al., 1994). The upper $200 \mathrm{~m}$ are important for krill advection and need to be represented accurately. At the same time, bottom topography has a large impact on the speed and the path of the ACC and its fronts in the region of interest (Gordon et al., 1978; Klinck, 1985) so it must be well represented. This model does not include sea ice dynamics which have a secondary effect on krill transport in the Scotia Sea. The focus is instead on the mean circulation patterns and their importance for transport of krill.

The present paper (Part I) develops a reference simulation of the circulation in the Scotia Sea and compares the simulated circulation to available data to validate the fields. Once the model is validated, simulated drifters are used to investigate the transport of krill and their fate in the Scotia Sea and environs. Additional simulations investigate the effect of changes in environmental conditions. Part II of the paper uses a krill growth model to determine krill growth and survival during the simulated transport.

\section{The circulation model}

The HOPS model is based on the Navier-Stokes equations in a rotating coordinate system, assuming the hydrostatic and the Boussinesq approximations (Spall, 1988; Spall and Robinson, 1989). The basic structure of the model is based on an early version of the Modular Ocean Model (MOM) (Bryan, 1969; Cox, 1984) and uses a double sigma stretched vertical coordinate system based on a piecewise linear sigma coordinate system (Simmons and Burridge, 1981). The state variables for the HOPS model are temperature, salinity and velocity. The model is solved numerically using a B-grid in space, and steps in time using leap-frog with lagged friction, as described in Bryan (1969). The small grid spacing $(10 \mathrm{~km})$ chosen for this study makes HOPS eddy admitting.

\subsection{Model configuration for the Scotia Sea}

The model domain includes the Antarctic and Subantarctic regions of the South Atlantic and South Pacific Oceans between the longitudes $85^{\circ} \mathrm{W}$ and $25^{\circ} \mathrm{W}$ and the latitudes $43^{\circ} \mathrm{S}$ and $73^{\circ} \mathrm{S}$ and is rotated counterclockwise by $22^{\circ}$ about the local vertical (Fig. 1B). The rotation of the model domain enables the ACC to enter Drake Passage in the east and exit into the South Atlantic without encountering model boundaries. A uniform $10-\mathrm{km}$ grid with 21 vertical layers is defined. Since the model uses terrain-following coordinates, the layers increase in thickness with depth so that depths of $4000 \mathrm{~m}$ can be resolved. A summary of the model setup is given in Table 1.

\subsubsection{Bottom topography}

The digital earth topography database of land and sea floor elevations ETOPO5 (NOAA, 1988) is used to specify the bottom topography and is smoothed according to the hydrostatic consistency criterion, which involves the bottom slope and the horizontal and vertical resolution of the grid to reduce pressure gradient errors and to avoid 
Table 1

Configuration of the HOPS model, values of parameters, and forcing functions used in the simulations

\begin{tabular}{ll}
\hline Model parameters & Values \\
\hline Horizontal resolution & $10 \times 10 \mathrm{~km}$, grid rotated counterclockwise by $22^{\circ}, 311 \times 211$ grid points (Longitude $\times$ Latitude) \\
Vertical resolution & 21 levels (finer at surface, coarser at bottom) \\
Time step & 36 min \\
Initialization & Antonov et al. (1998) and Boyer et al. (1998) climatological $T$ and $S$ fields with feature model of frontal \\
& jets \\
Continental boundaries & Represented by land mask with three islands (Falkland Islands, South Georgia, South Shetland Islands) \\
Ocean bathymetry & ETOPO5 data, with two slightly enhanced features, smoothed to respect pressure gradient error criterion \\
Eddy viscosity coefficient & Background $=5 \mathrm{~cm}^{2} \mathrm{~s}^{-1}$ \\
& Wind-mixed surface layer $=10^{3} \mathrm{~cm}^{2} \mathrm{~s}^{-1}$ \\
Bottom drag coefficient & $C_{\mathrm{D}}=2.5 \times 10^{-3}$ \\
Shapiro filter & Fourth order for momentum, tracers and transport \\
& Second-order for vorticity \\
Ekman factor & ekfac $=0.7$ \\
Dynamical surface forcing & Monthly wind stress from NCEP reanalysis \\
Baroclinic transport & Drake passage: $140 \mathrm{~Sv}$ \\
& Weddell gyre: $30 \mathrm{~Sv}$ \\
Model spin up time & Brazil current: $5 \mathrm{~Sv}$ \\
\hline
\end{tabular}

Abbreviations are used as follows: temperature (T), salinity $(S)$, National Centers for Environmental Prediction (NCEP), Sverdrup (Sv).

hydrostatic inconsistency (Messinger, 1982; Haney, 1991). Smoothing is necessary to avoid large systematic errors over the steep bottom slope created by the discrete form of the pressure gradient terms. For this implementation of HOPS, this criterion means that the continental slope off the Antarctic Peninsula, South America, and around South Georgia is approximately $10 \%$ gentler in the simulations than in reality. The position of the shelf break is similar to the actual shelf break, but the base of the slope extends at most one grid point $(10 \mathrm{~km})$ further into the deep ocean. In addition, two channels east of Burdwood Bank (south of the Falkland Islands) in the North Scotia Ridge near $54.5^{\circ} \mathrm{S}, 54^{\circ} \mathrm{W}$ and $53^{\circ} \mathrm{S}, 48.5^{\circ} \mathrm{W}$ (Fig. 1B) are deepened by approximately $150 \mathrm{~m}$ and widened by one grid point $(10 \mathrm{~km})$ to connect the deep waters south of the North Scotia Ridge with the Malvinas Chasm (cf. Fig. 1A). This is necessary because of flow constraints resulting from these topographic features which reduce flow through these channels and result in high flow speeds near the features, thereby making the flow unstable. At $64^{\circ} \mathrm{W}$ a ridge across the western Antarctic shelf near Anvers Island (cf. Fig. 1A) is raised to a depth of $100 \mathrm{~m}$ to better simulate the flow dynamics in the Bransfield Strait. Overall the bottom topography is defined to be as close as possible to the real conditions and includes all topographic features in this region (Fig. 1B).

\subsubsection{Boundary conditions, initialization, and forcing}

The land masses, including three major islands, the Falkland Islands, South Georgia, and the South Shetland Islands are defined as closed boundaries in the model domain which are rigid and impermeable. The barotropic transport of the flow is imposed on all open boundaries to represent the ACC (140 Sv; $\left.1 \mathrm{~Sv}=10^{6} \mathrm{~m}^{3} \mathrm{~s}^{-1}\right)$, the Brazil Current $(5 \mathrm{~Sv})$, and the Weddell Gyre (30 Sv).

Objectively analyzed annual mean fields of temperature and salinity obtained from the National Oceanographic Data Center (NODC) World Ocean Atlas (WOA) 1998 (Antonov et al., 1998; Boyer et al., 1998) are interpolated to the model grid as the initial condition. Local winds are strong over the model domain, with the time-averaged zonal wind stress in Drake Passage being a factor of three larger than mid-latitude winds (Trenberth et al., 1989). The National Centers for Environmental Prediction (NCEP) monthly wind stress, available over 13 years (1982-1994, Kalany et al., 1996) on a $2.5^{\circ} \times 2.5^{\circ}$ latitude and longitude grid is used.

The model circulation is forced by both local winds from a monthly climatology and barotropic transport 
at the model open boundaries, which represents the effect of global winds on the ACC. There is some indication (Gille et al., 2001) that higher frequency winds (approximately weekly period) influence ACC transport. At this level of simulation, we have chosen not to include this high-frequency variation in the local winds or the ACC transport.

\subsubsection{Frontal jets}

An important element of the Scotia Sea circulation is the observed fronts in the ACC (cf. Fig. 1A). Frontal jets are an important part of the ACC, as they provide flow speeds approaching $0.5 \mathrm{~m} \mathrm{~s}^{-1}$ that are 2-4 times the flow between the jets (Nowlin and Clifford, 1982; Hofmann, 1985; Orsi et al., 1995). The WOA 1998 climatologies are a smoothed representation of the meandering fronts, which produce unrealistically slow flow through Drake Passage. Feature models (e.g., Gangopadhyay et al., 1997) can create dynamically consistent features such as mesoscale rings, or frontal jets which are not resolved in climatological distributions. The frontal locations are well known (Orsi et al., 1995). The fronts are restored by creating additional data points at a $50-\mathrm{km}$ along front spacing with locations taken from Orsi et al. (1995). At each line segment defining a front, additional values of temperature and salinity are added at $2-\mathrm{km}$ across front intervals along a line that extends $150 \mathrm{~km}$ to each side and is perpendicular to the front. The standard depth, temperature and salinity values from the WOA climatologies are interpolated to these locations, as well as the temperature and salinity anomaly from the feature model (1) below. These additional data are interpolated onto the model grid using an optimal analysis procedure (Bretherton et al., 1976).

A temperature front is defined by a temperature anomaly (Ta) which is assumed to decay with depth $(z)$, and horizontal distance from the front location $\left(y_{r}\right.$, positive to the left, facing downstream) as

$\mathrm{Ta}=\Delta T y_{r} \mathrm{e}^{-\left(y_{r} / 2 W\right)^{2}} \mathrm{e}^{z / Z_{\mathrm{d}}} \min \left(1, \frac{-z}{Z_{\mathrm{s}}}\right)$,

where $\Delta T$ is the temperature change across the front, $W$ and $Z_{\mathrm{d}}$ are the width and depth scales of the front, respectively, and $Z_{\mathrm{s}}$ is the surface layer depth defined for each front. The minimum function keeps the frontal structure from intruding into the surface mixed layer, thereby defining the front for the depths between $Z_{\mathrm{s}}$ and $Z_{\mathrm{d}}$. A similar definition is used for the salinity anomaly. Five parameters derived from observations define each front (Table 2).
Table 2

Characteristics of the Subantarctic Front (SAF), the Polar Front (PF) and the Southern Antarctic Circumpolar Current Front (SACCF) used to determine the temperature and salinity anomalies for the feature model

\begin{tabular}{llllll}
\hline Front & $\mathrm{W}$ & $Z_{\mathrm{d}}$ & $Z_{\mathrm{s}}$ & $\Delta T\left({ }^{\circ} \mathrm{C}\right) /$ & $\Delta S / 100 \mathrm{~km}$ \\
& $(\mathrm{~km})$ & $(\mathrm{m})$ & $(\mathrm{m})$ & $100 \mathrm{~km}$ & \\
\hline SAF & 40 & 1200 & 150 & 0.96 & -0.15 \\
PF & 40 & 1200 & 150 & 1.2 & -0.15 \\
SACCF & 30 & 1200 & 300 & 1.0 & -0.09 \\
\hline
\end{tabular}

\subsubsection{Model spin-up}

The model is started on 1 October 1992 and a spin-up of two months is sufficient to develop a realistic flow field that reproduces flow features observed in the area, including mesoscale variability. The circulation model is then run for 10 months from 1 December 1992 until 30 September 1993.

\subsection{Drifter initialization and implementation}

Krill of all sizes can potentially be transported by ocean currents. However, adults are strong swimmers with swimming speeds up to 8 times their body length per second (Kils, 1982). For $40 \mathrm{~mm}$ krill, this swimming speed is similar to the average speed $\left(30 \mathrm{~cm} \mathrm{~s}^{-1}\right)$ along the SACCF (Orsi et al., 1995) so that adult krill is capable of swimming against prevailing currents and only larvae and juveniles are most likely passive drifters. Recent reviews suggest that krill may not be considered passively drifting particles, but that their behavior and swimming capabilities as adults may let them move to areas of their choice (Nicol, 2003a,b). However, it has been shown that advection by ocean currents is a major factor in determining the large-scale distribution (Marr, 1962; Murphy et al., 1998). Unfortunately, there have only been few studies of the potential effects of behavior in analyses of large-scale distribution (Murphy et al., 2004a). However, to test the possibility of krill transport between the Antarctic Peninsula and South Georgia it is necessary to make the assumption that krill are indeed passive drifters.

Krill have been observed to exhibit a diel vertical migrating pattern (Marr, 1962; Nast, 1979; Everson and Ward, 1980; Kalinowski and Witek, 1980; Godlewska, 1996), but the amplitude and length of time spent migrating varies greatly (Godlewska, 1996). Drifters are released into the simulated surface flow field at $50 \mathrm{~m}$ at 332 initial positions 
and starting at three different times because krill are found at average depths of 50-70 m (Godlewska, 1996). The trajectories provide transport pathways across the Scotia Sea that can be used for simulated circulation field validation, as well as for krill growth simulations discussed in Part II (Fach et al., 2006). Vertical migration is not included here assuming that the effect on drift trajectories is minimal because the velocity shear in the near surface $(\sim 100 \mathrm{~m})$ is very small.

\subsection{Simulations and sensitivity studies}

The model setup described above provides a reference simulation for comparison to other simulations investigating the effect of changing wind stress, ACC transport, and frontal location. The effect of changes in wind stress on the circulation in the study area is explored by increasing and decreasing the wind stress according to the NCEP wind data variability. The variance of 10 years of the NCEP wind time series (1985-1994) used to determine the interannual variability of wind over the entire study region showed a maximum variability of $11.45 \%$. Therefore, model sensitivity to a $20 \%$ increase and decrease in winds was tested to simulate the influence of observed variability and to include possible changes in wind stress due to climate change.

The transport through Drake Passage in the reference simulation is set to $140 \mathrm{~Sv}$. Whitworth et al. (1982) calculated a mean geostrophic transport of $103 \pm 2.6 \mathrm{~Sv}$ through Drake Passage, and Nowlin and Klinck (1986) reviewed transport estimates for Drake Passage and arrived at an average transport of $134 \pm 14 \mathrm{~Sv}$. According to these transport estimates, variations in the transport through Drake Passage of $12 \%$ were chosen to simulate possible interannual changes in the transport and its effect on krill transport.

Since the SACCF is the main transport mechanism of krill to South Georgia (Hofmann et al., 1998; Thorpe et al., 2002), it is also of interest to assess the influence of a change in location of this front. The SACCF meanders naturally (Nowlin and Klinck, 1986), but changes in environmental factors due to climate change may shift the fronts from their present location. Therefore, a third set of sensitivity simulations considers the flow that develops with the SACCF shifted $10 \mathrm{~km}$ to the north. A summary of all circulation sensitivity simulations is given in Table 3.
Table 3

Summary of the circulation sensitivity simulations showing the difference to the reference simulation and the figures displaying the results

\begin{tabular}{|c|c|c|}
\hline Simulation & Parameter changed & Results \\
\hline Reference & & Table 5, Figs. 2-8 \\
\hline Wind up & $20 \%$ increased winds & Table 5, Fig. 9A \\
\hline Wind down & $20 \%$ decreased winds & Table 5, Fig. 9B \\
\hline Transport up & $\begin{array}{l}12 \% \text { increased } \\
\text { transport }\end{array}$ & Fig. 9C \\
\hline Transport down & $\begin{array}{l}12 \% \text { decreased } \\
\text { transport }\end{array}$ & Fig. 9D \\
\hline Fronts & $\begin{array}{l}\text { SACCF moved } \\
10 \mathrm{~km} \text { to the north }\end{array}$ & Fig. 10 \\
\hline
\end{tabular}

The reference simulation used three years of NCEP winds (1992-1994), a 140 Sv transport through Drake Passage, and frontal locations taken from Orsi et al. (1995).

\section{Model validation}

\subsection{Circulation structure}

The circulation model in the reference configuration was run from 1 October 1992 to 30 September 1993. The initial barotropic streamfunction (Fig. 2A) shows general northeastward flow through Drake Passage and across the Scotia Sea. The transport through Drake Passage is approximately $140 \mathrm{~Sv}$ with three frontal regions (SAF, PF, and SACCF $)$. The SAF $(\approx 50 \mathrm{~Sv})$ flows north of Drake Passage close to the tip of South America. It turns north after Burdwood Bank to flow through a channel between Burdwood Bank and the North Scotia Ridge (cf. Fig. 1A) towards the Falkland Islands. At the northern boundary of the model domain, the SAF makes a sharp right turn and flows along $48^{\circ} \mathrm{S}$ to exit the domain to the east (Fig. 2A). The PF $(\approx 30 \mathrm{~Sv})$ flows parallel to the SAF and turns northeast to flow through a channel in the North Scotia Ridge $\left(53^{\circ} \mathrm{S}, 48.5^{\circ} \mathrm{W}\right)$ east of the SAF. It splits with part of it joining flow with the SAF further north, while the rest continues to the east, passing South Georgia to the south and exiting the model domain.

The SACCF has the weakest transport $(\approx 10 \mathrm{~Sv})$ (Fig. 2A) and flows close to the west Antarctic Peninsula continental shelf, parallel to the other two fronts. It turns north to flow along the east coast of South Georgia and to the east after passing South Georgia. The northern limb of the Weddell Gyre intrudes into the model domain at the southern model boundary at $51^{\circ} \mathrm{W}$. 

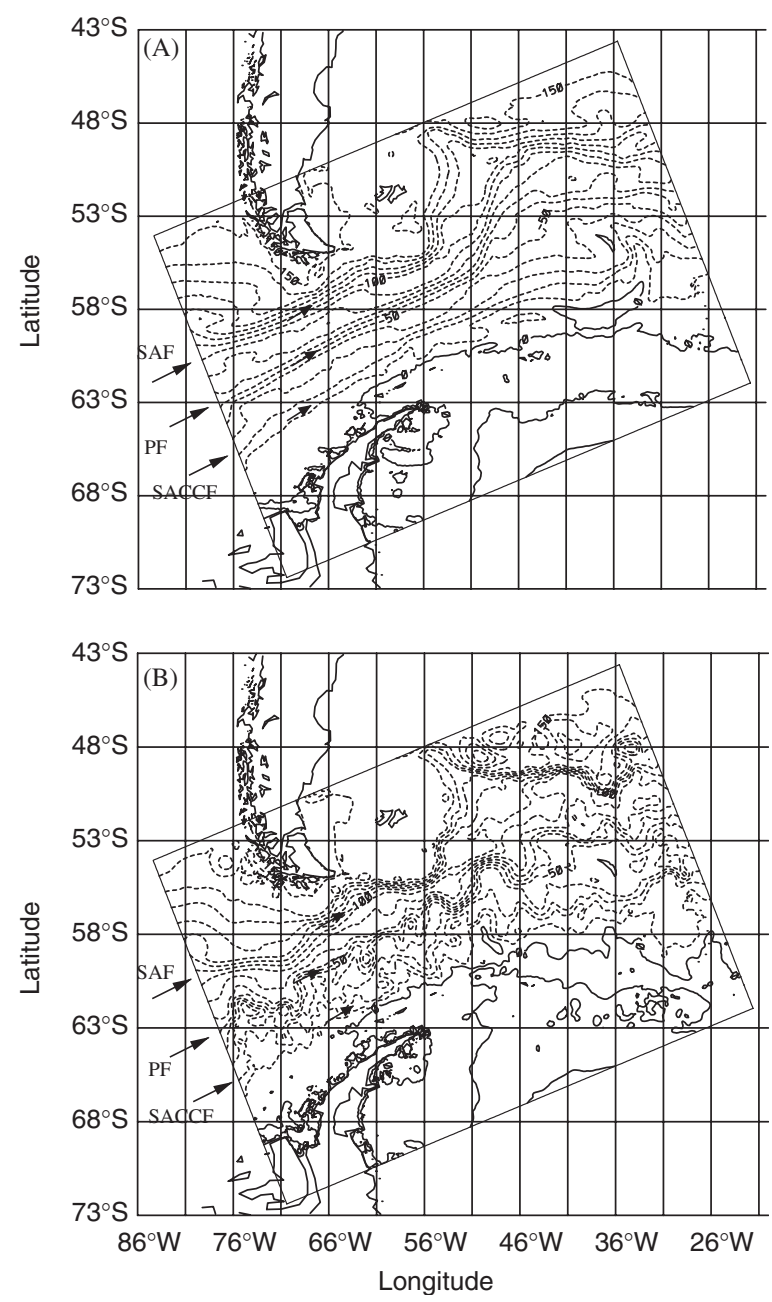

Fig. 2. Barotropic streamfunction (Sv) (A) at the start of the simulation (1 October) and (B) after 180 days of simulation (30 March). Contour interval is $10 \mathrm{~Sv}$. The direction of the flow is indicated by the arrows. Locations of the Subantarctic Front (SAF), the Polar Front (PF), and the Southern ACC Front (SACCF) are indicated by the large arrows, and the rotated rectangle shows the extent of the model domain.

After 180 days of simulation (30 March) mesoscale variability has developed and all three fronts show considerable meandering throughout their paths (Fig. 2B). Part of the SAF separates and joins the PF further east. The SACCF extends northeast across the Scotia Sea and does not turn northward to flow along the east side of South Georgia. In addition, a small fraction of the SACCF combined with flow from the PF moves east across the Scotia Sea and turns to flow north and then eastward before reaching South Georgia. Overall, the simulated surface circulation structure matches observations well (cf. Fig. 1A).

\subsection{Hydrography}

Model circulation is compared with measurements from the World Ocean Circulation Experiment (WOCE) A23 cruise that occurred in the eastern Scotia Sea near South Georgia (cf. Fig. 1B) between March and May 1995. The vertical temperature and salinity distributions along the WOCE A23 section (Figs. 3A,B) are smoothed and compared to the equivalent simulated vertical distributions from the same time of the year averaged over the month of April (Figs. 4A,B). The primary comparison is the location and strength of the three fronts, the position and southward extent of the $2.0^{\circ} \mathrm{C}$ isotherm, and the $34.4,34.6$, or 34.7 isohalines in the water column according to their association with different water masses. The 34.4 isohaline marks the boundary of the Antarctic Surface Water (AASW, fresher than 34.4), and Upper Circumpolar Deep Water (UCDW) is defined by salinity between 34.4 and 34.7 (Orsi et al., 1995). Lower Circumpolar Deep Water (LCDW) is defined by salinities above 34.7 (Orsi et al., 1995).

The simulated $2{ }^{\circ} \mathrm{C}$ isotherm starts out at $2100 \mathrm{~m}$ in the northern part of the simulated temperature distribution (Fig. 4A), $150 \mathrm{~m}$ below observations from the WOCE A23 cruise (Fig. 3A). It rises steeply at the position of the PF, then slowly shoals and reaches the surface about $500 \mathrm{~km}$ south of the observations (Fig. 3A).

The simulated location of the SACCF (Fig. 4) is approximately $80 \mathrm{~km}$ further north than observed (Fig. 3) while the simulated PF (Fig. 4) is about $100 \mathrm{~km}$ south of the observed location (Fig. 3). The isotherms in the simulated temperature distribution (Fig. 4A) level out in the southern part of the section and then deepen slightly, indicating a reversal in flow. This flow reversal results from an eddy spinning off the SACCF in this region and remaining south of the SACCF (Fig. 2B). The observations show a strong feature with cold water centered around station 45 (Fig. 3). This is a cold core eddy, which is not seen in the simulated circulation fields. The weak tilt of the isotherms and isohalines in the simulated property fields (Fig. 4) do not show the strong shear north of the PF seen in the WOCE A23 section (Fig. 3A), and the simulated PF has a weaker temperature gradient than does the observed PF.

The 34.6 and 34.7 isohalines start at 1400 and $1900 \mathrm{~m}$ in the simulated salinity field (Fig. 4B), 

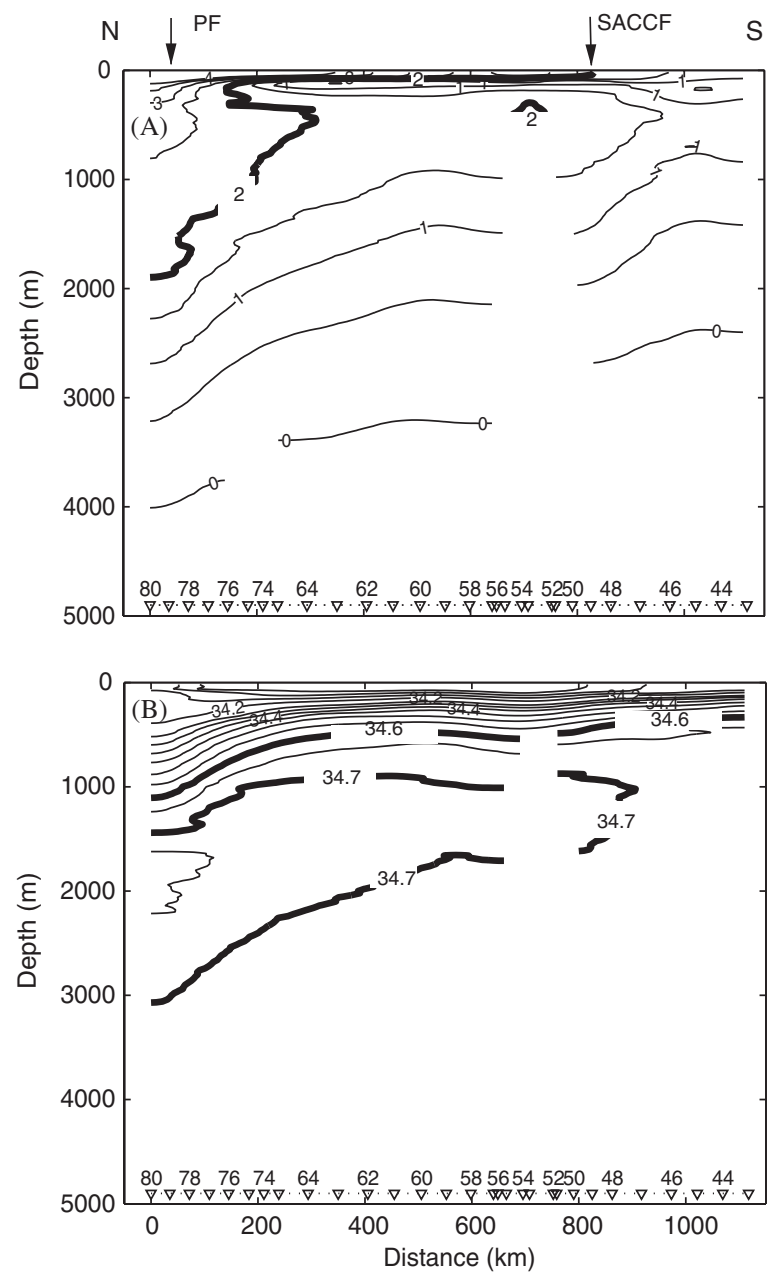

Fig. 3. Observed (A) potential temperature and (B) salinity from the WOCE A23 cruise, March-May 1995. Contour intervals are $0.5^{\circ} \mathrm{C}$ and 0.05 for temperature and salinity, respectively, and arrows indicate locations of the PF and SACCF. Thick lines mark the $2{ }^{\circ} \mathrm{C}$ isotherm (A) and the 34.6 and 34.7 isohalines (B). Station locations along the transect are shown by $\nabla$.

respectively, and then rise in the $\mathrm{PF}$, which is slightly lower than in the observations (Fig. 3B). The 34.6 isohaline shoals to $400 \mathrm{~m}$ at the southern end of the simulated salinity distribution (Fig. 4B), which is also observed. The tongue of water marked by the 34.7 isohaline rises across the whole section of simulated salinity and shoals as expected to approximately $1000 \mathrm{~m}$, but protrudes $100 \mathrm{~km}$ further to the south than seen in the observations (Fig. 3B).

The above comparisons show that the simulated isotherms and isohalines are smoother than the observations because they have been averaged. Also, the simulated vertical temperature structure shows isotherms that are deeper than observed and the PF and SACCF are further north of observed positions. However, these differences could be due to meanders of the fronts (either in the model or the observations).

\subsection{Model drifters}

The simulated circulation is used to track surface drifters over time. Verification of the simulated flow speeds and directions is done by releasing surface drifters in the model domain at locations that correspond to release sites of WOCE surface drifters. The mesoscale variability of the Scotia Sea and the equivalent variability in the simulated circulation fields precludes exact matching of the simulated and observed drifters. However, the general transport direction and average speeds of the observed and simulated paths should match.

Model drifters are released at 30 days intervals at the release points of nine WOCE surface drifters. The average speed for each model drifter is compared to the observed drifter (Table 4). Two examples of the comparison are shown (Fig. 5). WOCE drifter 22047 (Fig. 5), which was released in southern Drake Passage in January 1995, follows the SACCF. The observed trajectory of this drifter is east-northeastward from the tip of the Antarctic Peninsula across the Scotia Sea, passing South Georgia to the south. Eight meanders occur in the path of the drifter and its average speed is $0.234 \mathrm{~m} \mathrm{~s}^{-1}$. The simulated drifters, with various release times, follow the same trajectory until $48^{\circ} \mathrm{W}$, where drifters diverge north and south of the WOCE surface drifter path. The drifters released after 60 and 120 days of simulation turn northward, following the path of the SACCF northward, while the observed drifter moved eastward. The overall agreement of surface drifter paths is good, with all simulated drifter trajectories following the observed drifter trajectory closely. The WOCE drifter took 208 days to complete the trajectory shown in Fig. 5, while the simulated surface drifters took 216-336 days to cover the same distance. This difference in transport time arises because the simulated drifters are entrained in eddies at the beginning of their paths, which slows their progress. Overall the simulated surface drifters are slower than the WOCE surface drifters (Table 4).

WOCE drifter 22050 (Fig. 5) starts in March 1995 near the northern side of Drake Passage in the vicinity of the high-speed flow of the SAF. The 

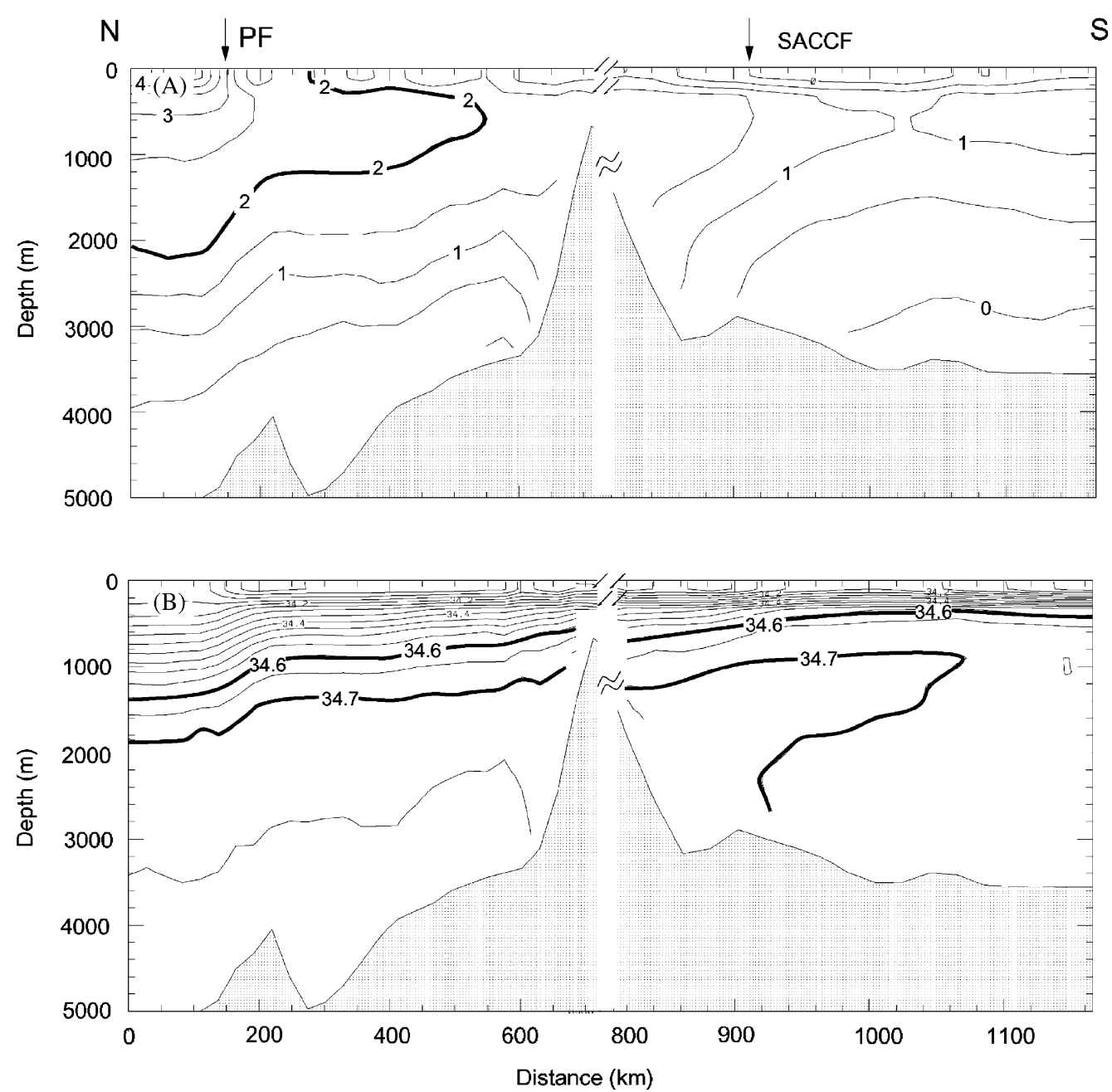

Fig. 4. Simulated (A) temperature and (B) salinity along the WOCE A23 section obtained by averaging the model-derived distributions for April. Contour intervals are $0.5^{\circ} \mathrm{C}$ and 0.05 for temperature and salinity, respectively, and arrows indicate the locations of two fronts, the PF and the SACCF. Thick lines mark the $2{ }^{\circ} \mathrm{C}$ isotherm (A) and the 34.6 and 34.7 isohalines (B). Pairs of lines $(/ /)$ indicate where the cruise tracks changed direction.

Table 4

Comparison of the average speed $\left(\mathrm{m} \mathrm{s}^{-1}\right)$ of WOCE surface drifters with the average surface speed calculated for the simulated surface drifters released at different days during the simulation

\begin{tabular}{|c|c|c|c|c|c|c|c|c|}
\hline \multirow[t]{2}{*}{ Observed WOCE drifter } & \multicolumn{6}{|c|}{ Simulated drifter speed } & \multirow{2}{*}{$\begin{array}{l}\text { WOCE } \\
\text { drifter avg. speed }\end{array}$} & \multirow[t]{2}{*}{ Error } \\
\hline & Day 30 & Day 60 & Day 90 & Day 120 & Day 150 & Avg. & & \\
\hline WOCE22045 & 0.296 & 0.282 & 0.285 & 0.293 & 0.186 & 0.268 & 0.374 & 0.283 \\
\hline WOCE22046 & 0.100 & 0.109 & 0.082 & 0.088 & 0.115 & 0.099 & 0.156 & 0.369 \\
\hline WOCE22047 & 0.080 & 0.066 & 0.116 & 0.142 & 0.159 & 0.113 & 0.234 & 0.517 \\
\hline WOCE22048 & 0.160 & 0.184 & 0.151 & 0.202 & 0.228 & 0.185 & 0.339 & 0.455 \\
\hline WOCE22049 & 0.133 & 0.197 & 0.132 & 0.152 & 0.148 & 0.152 & 0.212 & 0.281 \\
\hline WOCE22050 & 0.127 & 0.085 & 0.145 & 0.157 & 0.171 & 0.137 & 0.322 & 0.574 \\
\hline WOCE22108 & 0.157 & 0.157 & 0.306 & 0.220 & 0.306 & 0.229 & 0.458 & 0.499 \\
\hline WOCE22591 & 0.191 & 0.260 & 0.171 & 0.193 & 0.176 & 0.198 & 0.299 & 0.338 \\
\hline WOCE22594 & 0.199 & 0.253 & 0.196 & 0.314 & 0.365 & 0.265 & 0.321 & 0.173 \\
\hline
\end{tabular}

The average simulated drifter speed is based on all drifters released in the simulated circulation fields. The error is the calculated fractional error of average speed to observed average speed. 


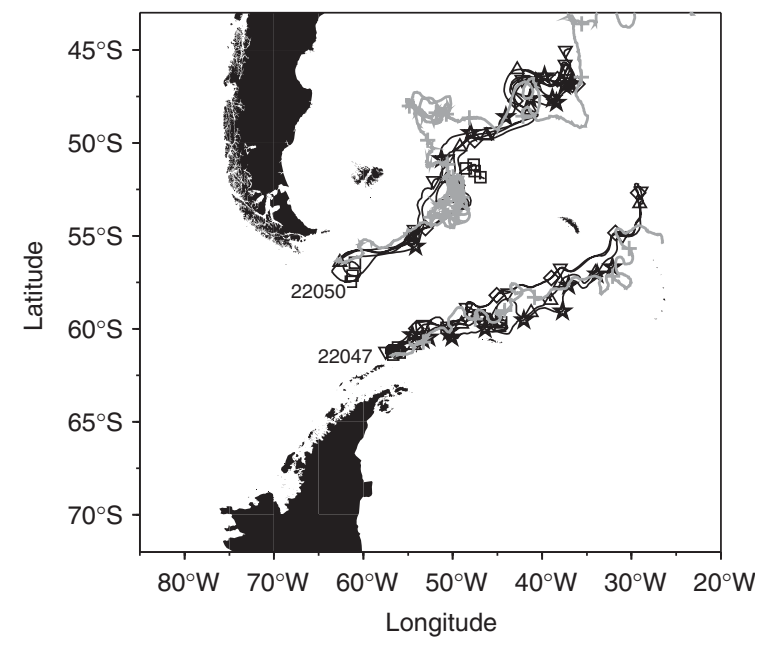

Fig. 5. Trajectories followed by WOCE surface drifter $22047(+$, gray line), and WOCE surface drifter $22050(+$, gray line), and those followed by simulated surface drifters released at day 30 $(\star)$, day $60(\square)$, day $90(\triangle)$, day $120(\nabla)$, day $150(\diamond)$. Symbols mark the position of the simulated and WOCE drifters at 30-day intervals.

average speed of this drifter is $0.322 \mathrm{~m} \mathrm{~s}^{-1}$ and the observed trajectory is eastward to the edge of the shallow South American continental shelf, where it turns northward between Burdwood Bank and South Georgia (cf. Fig. 1A). Near $54^{\circ} \mathrm{S}$ it is captured by an eddy in which it stays for approximately five months, then moves north and turns east near $48^{\circ} \mathrm{S}$ where it stays in another eddylike feature for three months. Near $30^{\circ} \mathrm{W}$ the drifter turns once again northward. It took 428 days to cover the distance shown in Fig. 5, with about eight months of this time spent in eddies, which reduced the overall transport distance.

The simulated surface drifters follow the same eastward path taken by WOCE drifter 22050 and turn north along the continental shelf east of Burdwood Bank. However, they are not transported as far north as WOCE drifter 22050, but rather turn east near $50^{\circ} \mathrm{S}$ and then follow a northeastward path. The simulated drifters move this distance in 216-336 days, because they are not trapped in eddies, as was WOCE drifter 22050. Only the simulated drifter released on day 60 is entrained into a large eddy near its release point and does not move as far northeast as the others. The simulated drifter paths match the observed drifter paths in the first part of the trajectory, but diverge from the path of WOCE drifter 22050 after passing the Falkland
Islands and move northeastward. Again the average speeds of the simulated drifters are slower than that of WOCE drifter 22050 (Table 4).

The best agreement of simulated and observed drifter speeds (Table 4) is with WOCE drifter 22594. The model-derived speeds are only $17 \%$ slower than the observed drifter speeds. The worst agreement is with WOCE drifter 22050, which is $57 \%$ faster than the equivalent simulated drifters. On average the model drifters are $38.5 \%$ slower than the observed drifters.

\subsection{Model sensitivity}

To test the influence of wind on the regional circulation the flow speed and direction of eight simulated surface drifters are used to examine the model sensitivity to wind. The starting positions of the drifters (Table 5) were chosen to cover different environments in the study area (Fig. 6).

Decreasing wind stress over the total study region by $20 \%$ changes the surface flow speeds of the drifters over a large range from $-68 \%$ to $36 \%$ (Table 5). Five of the drifters react with increased surface speeds and changed flow direction, while the other three drifters show decreased surface speeds with a change in direction. The smallest change in drifter behavior, a $8 \%$ increase in speed and a $30^{\circ}$ change in direction, occurs on the Weddell Sea shelf edge (drifter 7). The largest change occurs at the southwestern Antarctic Peninsula (drifter 6), with a $68 \%$ decrease of surface speed and a $6^{\circ}$ change in direction (Table 5).

Increasing wind stress by $20 \%$ changes the surface speed and direction of the eight drifters from $-18 \%$ to $23 \%$ (Table 5 ), but the range is less than that observed for decreased wind stress. The drifter at the western Antarctic Peninsula (drifter 6) experiences the least change of $3 \%$ increased speed and a $141^{\circ}$ change in direction. The drifters that show changes in speed and direction are not necessarily the same drifters as those in the decreased wind simulations. For example drifter 2, located in the SAF, experiences decreased speeds in both cases while drifter 1, in the Bransfield Strait, experiences increased surface speed with decreased winds and decreased surface speed with increased wind. In contrast, drifter 6 at the southwest Antarctic Peninsula, experiences strongly decreased surface flow speeds $(68 \%)$ with decreased winds and slightly increased flow speed $(3 \%)$ with increased wind. 
Table 5

Average simulated surface layer flow speed and direction, and Ekman flow speed and direction over the upper $100 \mathrm{~m}$ for eight drifters forced with $\pm 20 \%$ variation in the NCEP wind fields

\begin{tabular}{|c|c|c|c|c|c|c|c|c|c|}
\hline \multirow{2}{*}{$\begin{array}{l}\text { Wind } \\
\text { forcing }\end{array}$} & & \multicolumn{2}{|c|}{ Initial location } & \multicolumn{3}{|c|}{ Surface flow } & \multicolumn{3}{|c|}{ Ekman flow } \\
\hline & & $\begin{array}{l}\text { Longitude } \\
\left({ }^{\circ} \mathrm{W}\right)\end{array}$ & $\begin{array}{l}\text { Latitude } \\
\left({ }^{\circ} \mathrm{S}\right)\end{array}$ & $\begin{array}{l}\text { Speed } \\
\left(\mathrm{cm} \mathrm{s}^{-1}\right)\end{array}$ & $\begin{array}{l}\text { Change } \\
(\%)\end{array}$ & $\begin{array}{l}\text { Direction } \\
\left({ }^{\circ} \text { true }\right)\end{array}$ & $\begin{array}{l}\text { Speed } \\
\left(\mathrm{cm} \mathrm{s}^{-1}\right)\end{array}$ & $\begin{array}{l}\text { Change } \\
(\%)\end{array}$ & $\begin{array}{l}\text { Direction } \\
\left({ }^{\circ} \text { true }\right)\end{array}$ \\
\hline \multirow[t]{8}{*}{ NCEP } & 1 & 59.0 & 63.0 & 0.57 & & 312 & 0.7 & & 58 \\
\hline & 2 & 60.5 & 56.0 & 6.94 & & 167 & 0.57 & & 66 \\
\hline & 3 & 56.0 & 58.0 & 2.60 & & 300 & 0.5 & & 67 \\
\hline & 4 & 63.5 & 64.0 & 3.85 & & 138 & 0.68 & & 60 \\
\hline & 5 & 53.0 & 63.0 & 6.35 & & 1 & 0.65 & & 53 \\
\hline & 6 & 69.5 & 66.0 & 3.07 & & 140 & 0.56 & & 82 \\
\hline & 7 & 53.0 & 65.0 & 3.08 & & 63 & 0.93 & & 49 \\
\hline & 8 & 39.0 & 56.0 & 8.69 & & 124 & 0.22 & & 333 \\
\hline NCEP & 1 & 59.0 & 63.0 & 0.89 & 36 & 263 & 0.56 & -25 & 58 \\
\hline \multirow[t]{7}{*}{$-20 \%$} & 2 & 60.5 & 56.0 & 4.79 & -44 & 248 & 0.46 & -24 & 66 \\
\hline & 3 & 56.0 & 58.0 & 3.59 & 28 & 336 & 0.4 & -25 & 67 \\
\hline & 4 & 63.5 & 64.0 & 3.23 & -19 & 161 & 0.54 & -26 & 60 \\
\hline & 5 & 53.0 & 63.0 & 7.82 & 19 & 350 & 0.52 & -25 & 53 \\
\hline & 6 & 69.5 & 66.0 & 1.83 & -68 & 146 & 0.45 & -24 & 82 \\
\hline & 7 & 53.0 & 65.0 & 3.34 & 8 & 30 & 0.74 & -26 & 49 \\
\hline & 8 & 39.0 & 56.0 & 11.88 & 30 & 122 & 0.18 & -26 & 333 \\
\hline NCEP & 1 & 59.0 & 63.0 & 0.54 & -5 & 162 & 0.84 & 17 & 58 \\
\hline \multirow[t]{7}{*}{$+20 \%$} & 2 & 60.5 & 56.0 & 5.85 & -18 & 173 & 0.69 & 17 & 66 \\
\hline & 3 & 56.0 & 58.0 & 2.58 & -0.7 & 252 & 0.6 & 17 & 67 \\
\hline & 4 & 63.5 & 64.0 & 5.00 & 23 & 141 & 0.82 & 17 & 60 \\
\hline & 5 & 53.0 & 63.0 & 5.37 & -18 & 2 & 0.78 & 17 & 53 \\
\hline & 6 & 69.5 & 66.0 & 3.14 & 3 & 141 & 0.67 & 16 & 82 \\
\hline & 7 & 53.0 & 65.0 & 3.63 & 15 & 64 & 1.11 & 16 & 49 \\
\hline & 8 & 39.0 & 56.0 & 9.52 & 9 & 125 & 0.27 & 18 & 333 \\
\hline
\end{tabular}

The simulated speed and direction values are 30-day averages for December. The percent change in surface and Ekman flow speeds is computed relative to the winds used for the reference simulation.

Changes in the wind stress distribution used to force the model have different effects on the surface flow speed and direction in different areas in the model domain. A $20 \%$ decrease in the wind changes the surface flow speeds and direction of the surface flow more than a $20 \%$ increase in wind stress. The increase or decrease of the wind has an almost uniform influence on the Ekman flow, which increases by approximately $17 \%$ with increased wind and decreases by approximately $25 \%$ with decreased wind stress (Table 5).

In Bransfield Strait the influence of wind is particularly interesting as this is an area of consistent krill spawning (Marr, 1962; Siegel, 1992). For normal wind conditions, drifter 1 (Fig. 6A) flows south in Bransfield Strait and then turns west, exits the Strait, and becomes entrained in the SACCF. Increased winds enhance northward Ekman transport, which moves drifter 1 into the ACC sooner (Fig. 6A). The simulated trajectories for this drifter for normal and increased winds are similar, except for a northward shift during increased wind conditions (Fig. 6A).

A $20 \%$ reduction in the wind results in the drifter remaining longer in Bransfield Strait before becoming entrained into the ACC (Fig. 6A). Under decreased winds, eight months of the total transport time is spent in or near Bransfield Strait. As a consequence, this drifter is transported only as far as $59^{\circ} \mathrm{W}$, while the other two drifters are transported halfway across the Scotia Sea in the same time. Clearly, increased wind enhances transport towards South Georgia by accelerating offshore transport and entrainment into the ACC, and moves the drifters on a more northward trajectory. Decreased wind speeds slow and retain particles along the northern Antarctic Peninsula. 

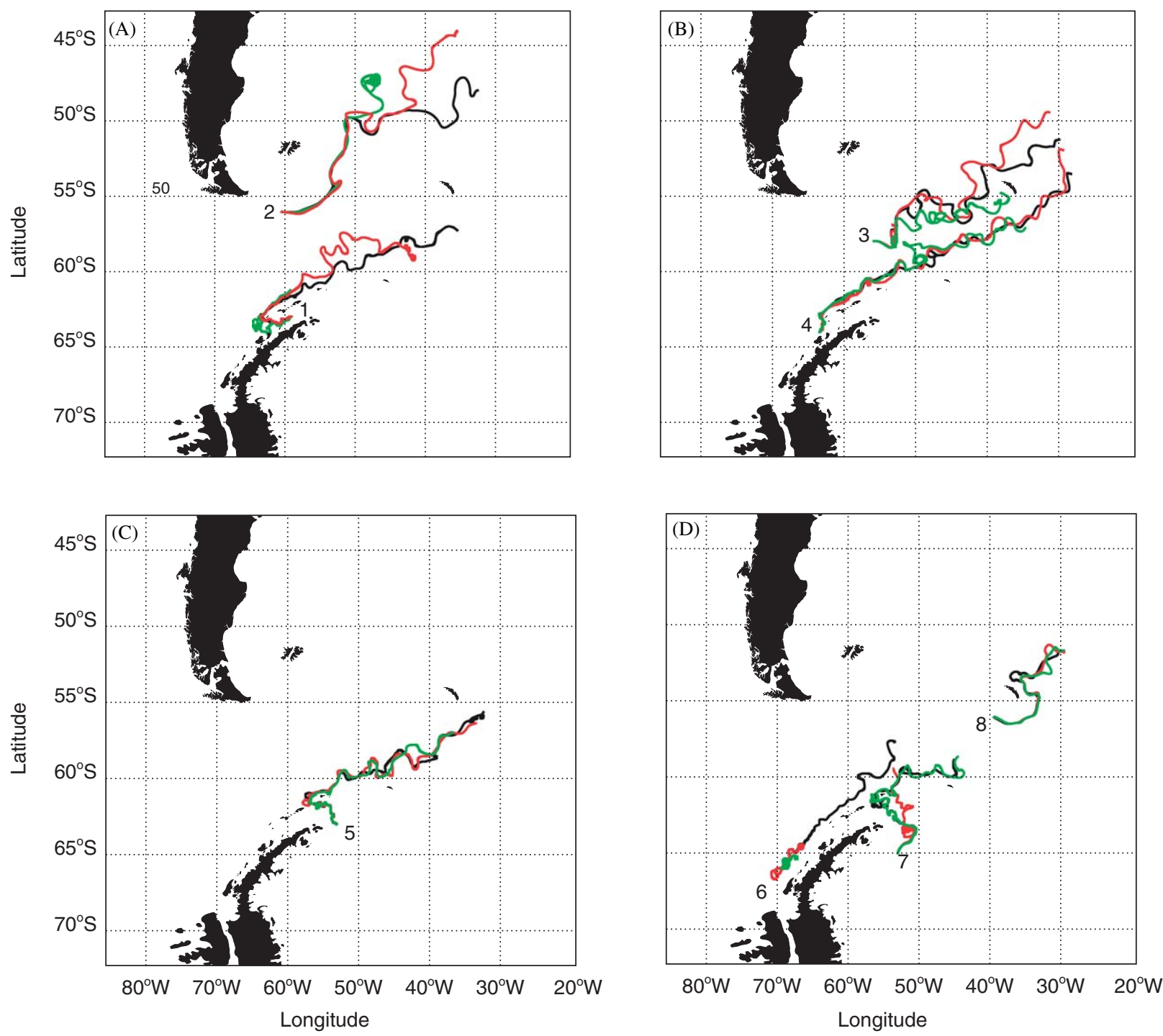

Fig. 6. Simulated surface drifter trajectories for drifters (A) 1 and 2, (B) 3 and 4, (C) 5, and (D) 6, 7, and 8, released in December that experience NCEP winds (solid line), NCEP winds with a $20 \%$ increase in wind speed (red line), and NCEP winds with a $20 \%$ decrease in wind speed (green line). Numbers indicate the release point of each drifter as given in Table 5 .

The above analysis shows that the surface wind stress has a minor influence on the overall circulation pattern, indicating that the simulated circulation is largely controlled by the initial density distribution, the frontal features, and the bottom topography. However, wind stress does have a strong effect on the exchange between the continental shelf region of the Antarctic Peninsula and the ACC due to the contribution of the Ekman transport to the overall large-scale surface flow.

\section{Krill transport results}

\subsection{Reference simulation}

Drifters were released in the model solution at 332 locations in three months during which krill spawn. Each drifter was characterized by its approach to South Georgia. The simulated drifter pattern resulting from a December release (Fig. 7A) in the reference circulation simulation shows a broad area along the western Antarctic Peninsula 

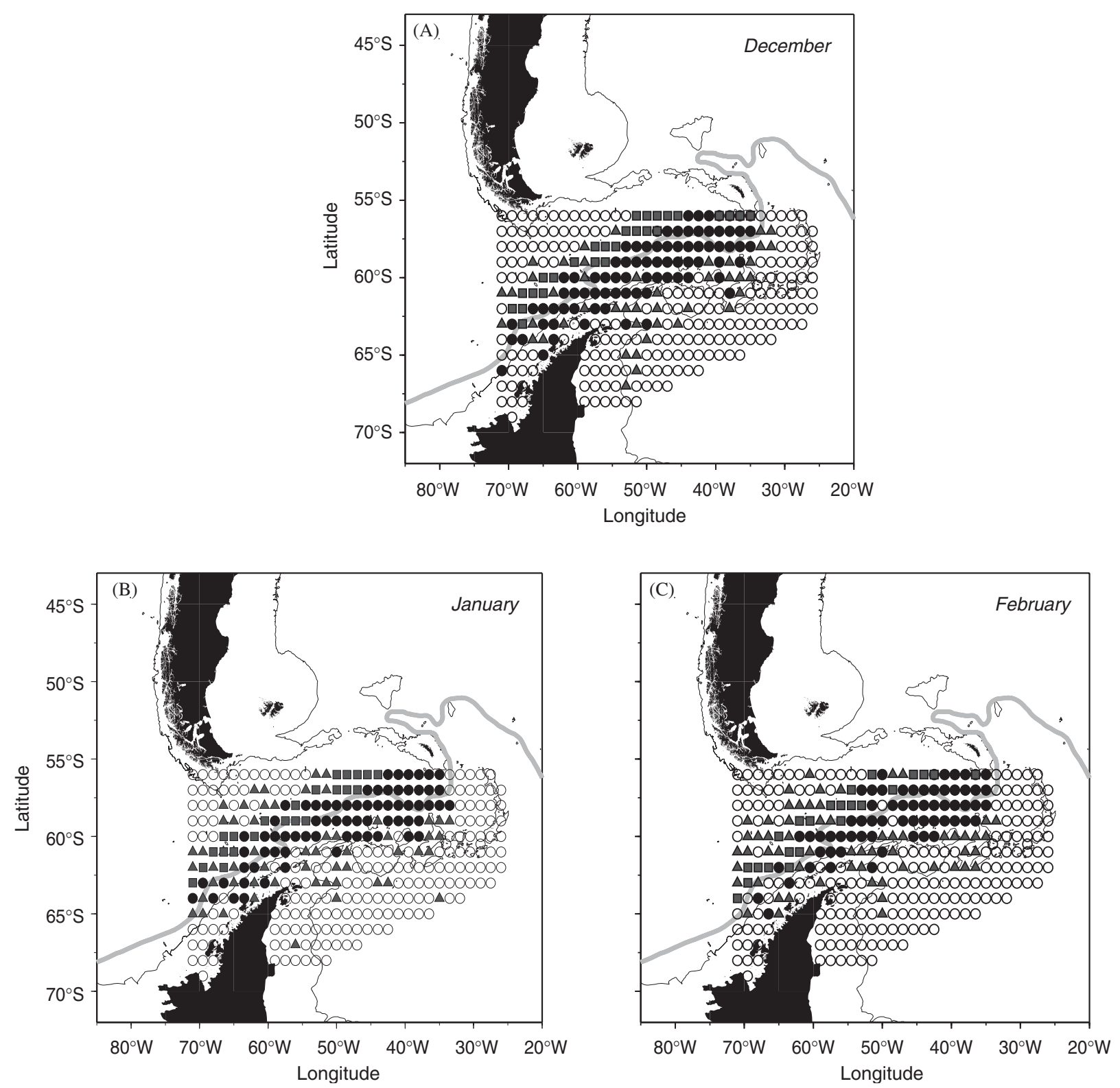

Fig. 7. Initial positions at which surface drifters were released in the simulated circulation fields on (A) 1 December, (B) 1 January, and (C) 1 February. The drifter release points are separated into groups that correspond to drifters that reach South Georgia $(\bullet)$, those that approach South Georgia from the north ( $\boldsymbol{\square})$, those that arrive to within $600 \mathrm{~km}$ of South Georgia $(\boldsymbol{\Delta})$, and those that do not reach South Georgia (o). The thick gray line shows the position of the SACCF and the thin black lines indicate the 2000-m isobath.

extending into the Scotia Sea, from the continental shelf of the Peninsula into Drake Passage, from where particles can reach South Georgia in the 10 months of the simulation. This region includes 81 drifter release points and roughly coincides with the path of the SACCF. North of this area, in the center of the Drake Passage, is a narrow band of locations from which drifters can reach South Georgia from the north. In addition, drifters from four locations south of South Georgia approach the Island from the north. North of this narrow band are several locations from which drifters are transported to within $600 \mathrm{~km}$ of South Georgia. Six locations along the Weddell Sea continental shelf break, east of the Antarctic Peninsula close to the 2000-m isobath, and several locations east of the tip of the Antarctic Peninsula are sites that allow drifters to be transported to within $600 \mathrm{~km}$ of South Georgia in 
10 months. Drifters originating in the east of the Scotia Sea do not reach South Georgia directly, but rather move within $600 \mathrm{~km}$ of the Island in the oneyear simulation. Drifters originating from the spawning area between $35^{\circ} \mathrm{W}$ and $25^{\circ} \mathrm{W}$ (Fig. 7A) are not transported near South Georgia but are transported to the east, away from the Island. Five release points in Bransfield Strait result in particle trajectories that do not reach the vicinity of South Georgia because of transport times longer than 10 months. Drifters originating along the southwestern shelf of the Antarctic Peninsula west of $65^{\circ} \mathrm{W}$, where another spawning area is located, do not reach South Georgia. Instead, they are transported only small distances to the northeast along the continental shelf. Overall, 108 of the 332 released drifters reach South Georgia and 44 come within $600 \mathrm{~km}$ of the Island (Table 6).

The simulated transport pattern for a January release (Fig. 7B) shows that drifters released at the northern tip of the Antarctic Peninsula and in the eastern Bransfield Strait no longer reach South Georgia. Again a broad area of release locations along the Antarctic Peninsula from which particles can reach South Georgia is present, coinciding with the location of the SACCF. However, a January release results in a reduction in drifters that approach South Georgia from the south (Table 6). To the north of this band there are again several locations from where particles can reach South Georgia from the north, but they declined from 27 to 23 (Table 6). Only one location in the Weddell Sea and seven east of the tip of the Antarctic Peninsula result in drifters transported to within $600 \mathrm{~km}$ of South Georgia (Table 6). Overall 93 drifters of the 332 released reach South Georgia, while 57 are transported to within $600 \mathrm{~km}$ of the Island (Table 6).

The simulated transport pattern for a February release (Fig. 7C) shows even fewer locations at the western Antarctic Peninsula shelf that allow drifters to reach South Georgia. The total number of drifters reaching South Georgia decreased from 108 in December and 93 in January to 87 in February (Table 6). Drifters released at three additional sites in the western Bransfield Strait do not reach South Georgia, as well as those released at three sites west of Bransfield Strait and two sites in

Table 6

Summary of the total number of simulated drifters reaching South Georgia (SG), reaching South Georgia from the north (north SG), reaching South Georgia from the south (south SG), reaching within $600 \mathrm{~km}$ of South Georgia (600 km SG), and not reaching South Georgia (not reach) obtained for different circulation scenarios and release times

\begin{tabular}{|c|c|c|c|c|c|c|}
\hline \multirow[t]{2}{*}{ Simulation type } & \multirow[t]{2}{*}{ Release time } & \multicolumn{5}{|c|}{ Total number of drifters } \\
\hline & & At SG & North SG & South SG & $600 \mathrm{~km} \mathrm{SG}$ & Not reach \\
\hline \multirow{3}{*}{ Reference } & Dec. & 108 & 27 & 81 & 44 & 180 \\
\hline & Jan. & 93 & 23 & 70 & 57 & 182 \\
\hline & Feb. & 87 & 23 & 64 & 60 & 185 \\
\hline \multirow{3}{*}{$\begin{array}{l}20 \% \text { increased } \\
\text { winds }\end{array}$} & Dec. & 105 & 21 & 84 & 51 & 176 \\
\hline & Jan. & 96 & 13 & 83 & 54 & 182 \\
\hline & Feb. & 84 & 24 & 60 & 58 & 190 \\
\hline \multirow{3}{*}{$\begin{array}{l}20 \% \text { decreased } \\
\text { winds }\end{array}$} & Dec. & 93 & 19 & 74 & 54 & 185 \\
\hline & Jan. & 90 & 23 & 67 & 61 & 181 \\
\hline & Feb. & 84 & 16 & 68 & 56 & 192 \\
\hline \multirow{3}{*}{$\begin{array}{l}12 \% \text { increase } \\
\text { in DP } \\
\text { transport }\end{array}$} & Dec. & 108 & 22 & 86 & 40 & 184 \\
\hline & Jan. & 91 & 26 & 65 & 58 & 183 \\
\hline & Feb. & 83 & 20 & 63 & 58 & 191 \\
\hline \multirow{3}{*}{$\begin{array}{l}12 \% \text { decrease } \\
\text { in DP } \\
\text { transport }\end{array}$} & Dec. & 99 & 28 & 71 & 56 & 177 \\
\hline & Jan. & 90 & 18 & 72 & 60 & 182 \\
\hline & Feb. & 83 & 22 & 61 & 69 & 180 \\
\hline \multirow{3}{*}{$\begin{array}{l}\text { SACCF moved } \\
10 \mathrm{~km} \text { north }\end{array}$} & Dec. & 97 & 25 & 72 & 48 & 187 \\
\hline & Jan. & 100 & 21 & 79 & 55 & 177 \\
\hline & Feb. & 89 & 25 & 64 & 62 & 181 \\
\hline
\end{tabular}

Drake Passage is abbreviated as DP. Drifter release times are 1 December (Dec.), 1 January (Jan.), and 1 February (Feb.). 
the Scotia Sea near $50^{\circ} \mathrm{W}$. Drifters originating in the Weddell Sea are transported into the vicinity of the Island. Overall, 87 drifters reach South Georgia and 60 are transported to within $600 \mathrm{~km}$ of this island (Table 6).

This shows that along the Antarctic Peninsula an early particle release increases chances of reaching South Georgia, especially of drifters from the main spawning area off the west Antarctic Peninsula and the Bransfield Strait. Late release times also negatively affect the chances of krill transport from the Weddell Sea that are otherwise transported to within $600 \mathrm{~km}$ of South Georgia.

The simulated drifters can reach South Georgia from the south or the north of the Island, depending on their release locations (Fig. 8). Transport of simulated particles onto the continental shelf of the Island is rare (Fach, 2003), most of the drifters pass near South Georgia (Fig. 8).

\subsection{Effect of environmental changes}

The simulated drifter trajectories show that it is possible for krill originating in known spawning areas along the western Antarctic Peninsula plus the Weddell Sea to be transported to South Georgia. Thus, the influence of variable environmental conditions such as wind, the transport through Drake Passage and the location of the fronts on this basic transport pattern are next assessed. For

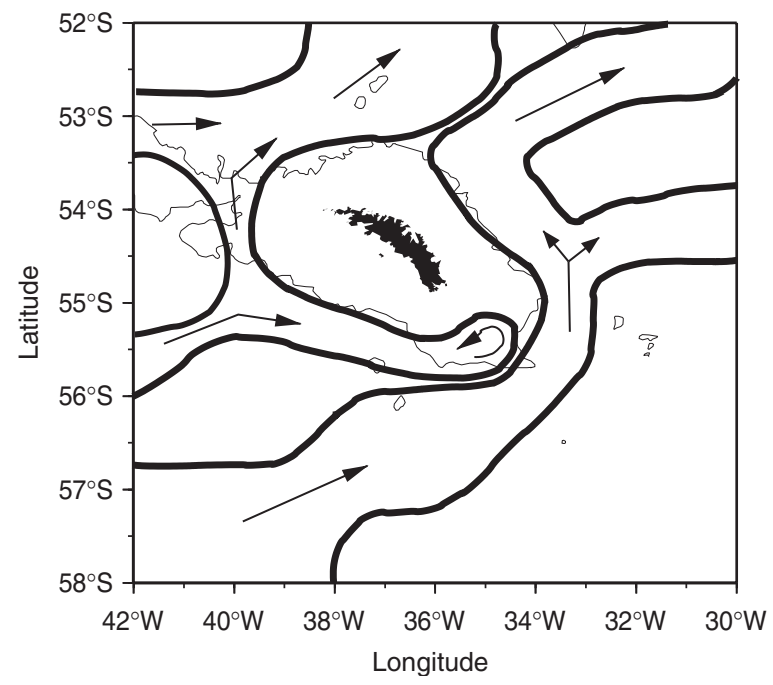

Fig. 8. Envelope of the simulated surface drifter trajectories of a January release in the reference simulation reaching South Georgia from the north and south. Arrows indicate the direction of flow. Thin black line indicates the 2000-m isobath. simplicity, only the transport patterns for a January release are shown. Results for other release times are summarized in Table 6 and details are given in Fach (2003).

\subsubsection{Wind stress}

The simulated transport pattern (Fig. 9A) for drifters released in a circulation field obtained using increased wind speed (Table 3), shows a pattern similar to that obtained using the reference simulation (Fig. 7B). The drifters originating at sites in Bransfield Strait that did not reach South Georgia in the reference simulation remain the same. However, drifters from two additional release sites did not reach South Georgia, because the drifters were retained in the Bransfield Strait for several months before being advected into the fast-moving currents of the SACCF. The increased Ekman transport increased the entrainment of drifters originating in Bransfield Strait into the ACC, as seen in Section 3.3.2. (drifter 1), but this advection into the ACC is not significant enough to transport drifters to South Georgia in the nine months of the simulation. Overall drifters originating at 13 more sites than in the reference January release simulation reached South Georgia from the south, but only 13 reached the Island from the north, 10 less than in the reference simulation (Table 6).

The simulated drifter transport patterns obtained with a $20 \%$ reduction in wind speed (Figs. 9B) are similar to that obtained from the reference simulation (Fig. 7A). The primary difference is that fewer sites in Bransfield Strait allow drifters to reach South Georgia (Figs. 9B). Another effect is that fewer drifters reach South Georgia from the north side (Table 6) because many drifters first approach the Island from the south, turn northward and are transported along the western side of the Island (Fig. 8). With reduced winds these drifters do not move far enough to be transported along the northern side of South Georgia.

Increased wind stress over the study area does not facilitate transport of more drifters from Bransfield Strait towards South Georgia and it has a negative influence on transport times from the Weddell Sea. Decreased wind stress affects drifters from the Bransfield Strait and the Weddell Sea negatively.

\subsubsection{Transport through Drake Passage}

The simulated drifter transport pattern for a circulation field produced by a $12 \%$ increase in transport through Drake Passage (Fig. 9C) shows 

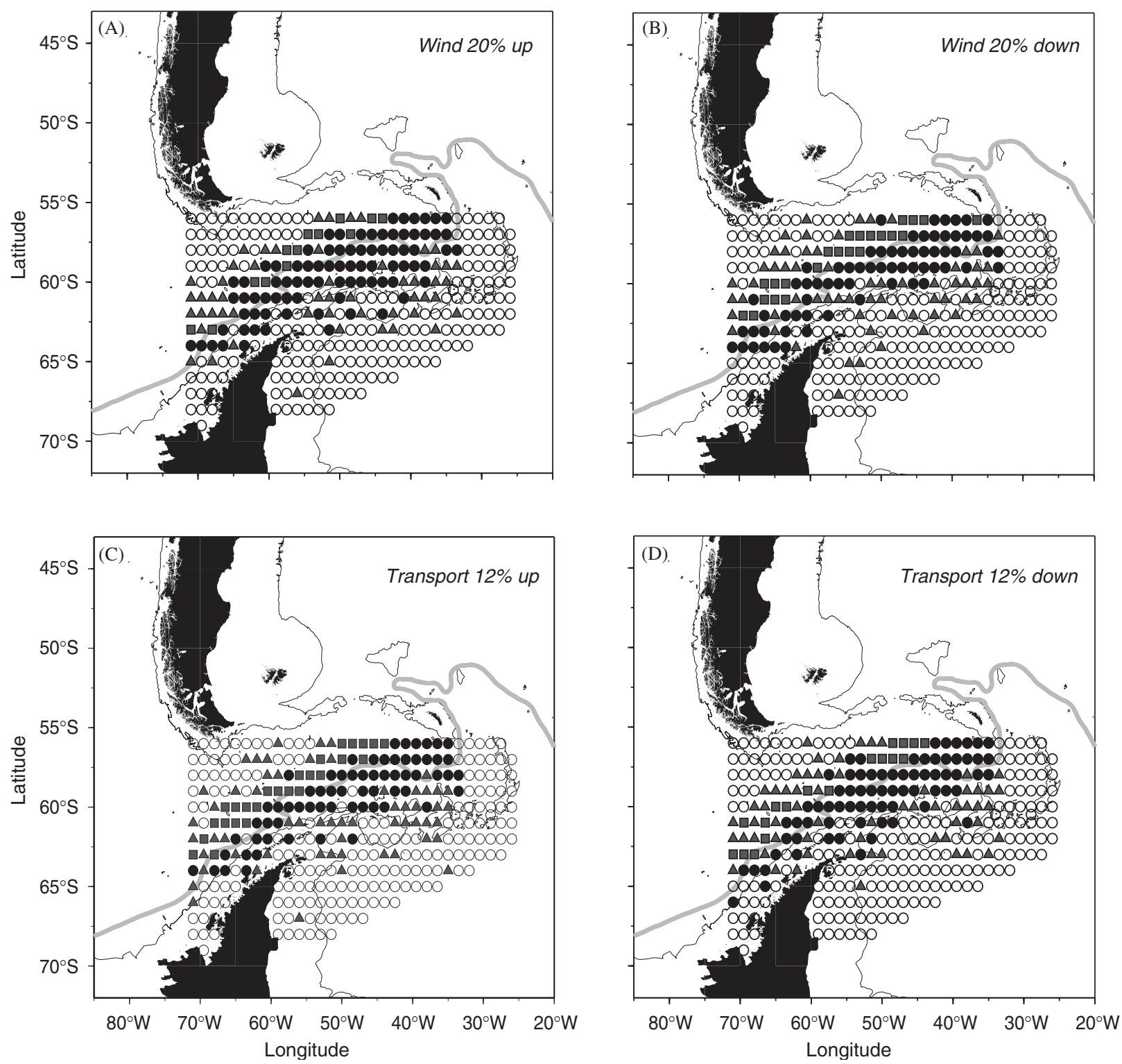

Fig. 9. Initial positions at which surface drifters were released in January in the simulated circulation fields obtained using (A) $20 \%$ increased wind speeds, (B) $20 \%$ decreased wind speeds, (C) 12\% increased transport through Drake Passage, and (D) $12 \%$ decreased transport through Drake Passage. The drifter release points are separated into groups that correspond to drifters that reach South Georgia $(\bullet)$, those that approach South Georgia from the north $(\mathbf{\square})$, those that arrive to within $600 \mathrm{~km}$ of South Georgia $(\boldsymbol{\Delta})$, and those that do not reach South Georgia ( $)$. The thick gray line shows the position of the SACCF and the thin black lines indicate the 2000-m isobath.

that drifters originating in Bransfield Strait do not reach South Georgia. The currents in Bransfield Strait are not strongly influenced by the transport through Drake Passage. Overall the result of this simulation is similar to the simulation with $20 \%$ increased winds (Fig. 9A vs. C). For a $12 \%$ decrease in transport through Drake Passage the simulated drifter transport patterns produced for all three release times (Fig. 9D, Table 6) are similar to those obtained in the reference simulation (Figs. 7A-C). These simulations also show that earlier release times favor transport to South Georgia (Table 6).

\subsubsection{Location of the southern ACC front}

When the SACCF is moved $10 \mathrm{~km}$ north of its climatological location, the simulated drifter transport pattern produced by a December and January release (Figs. 10A,B) shows that drifters originating 

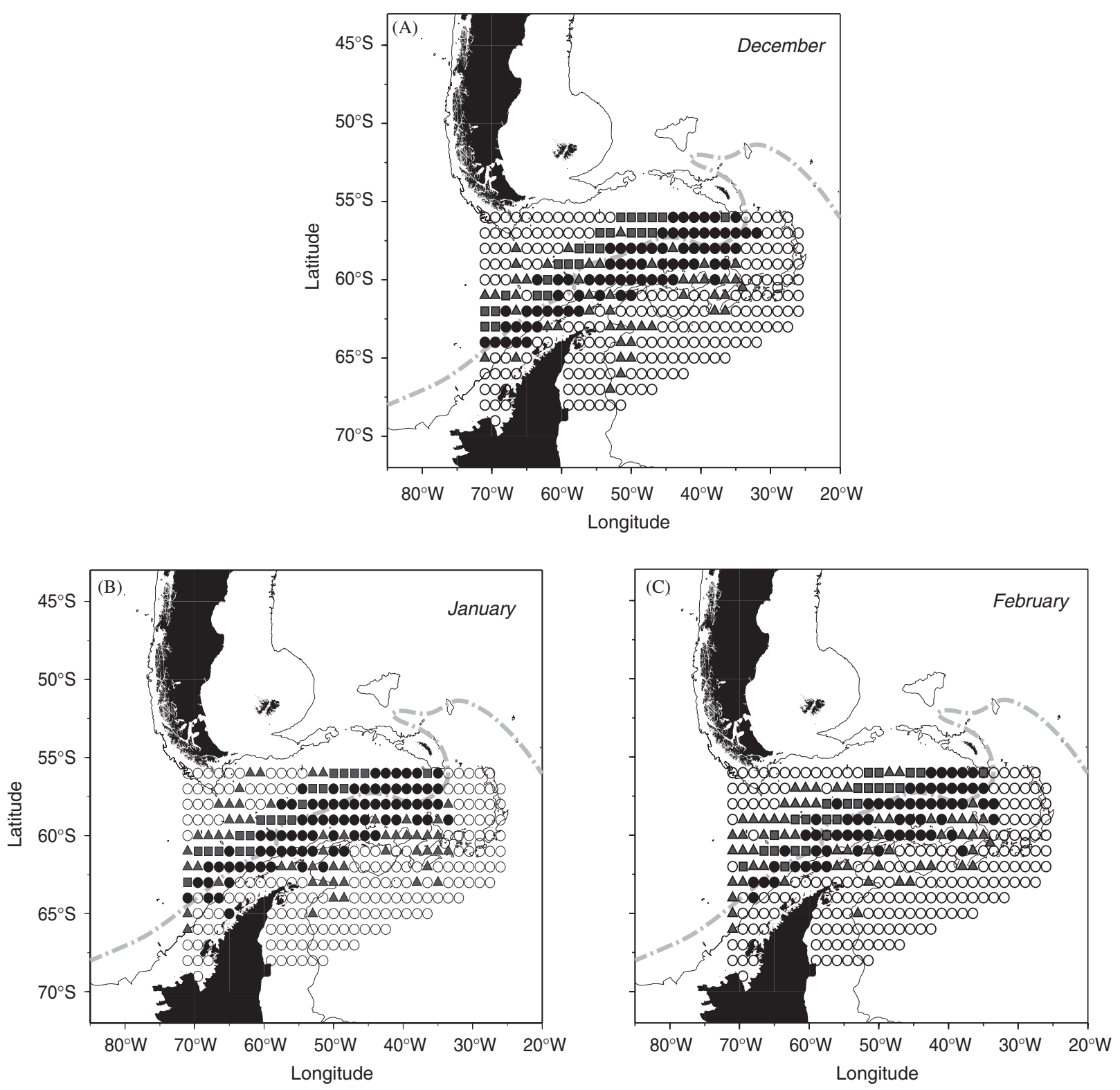

Fig. 10. Initial positions at which surface drifters were released in the simulated circulation fields obtained with the SACCF moved $10 \mathrm{~km}$ to the north on (A) 1 December, (B) 1 January, and (C) 1 February. The drifter release points are separated into groups that correspond to drifters that reach South Georgia $(\bullet)$, those that approach South Georgia from the north $(\mathbf{\square})$, those that arrive to within $600 \mathrm{~km}$ of South Georgia ( $\mathbf{\Delta})$, and those that do not reach South Georgia (o). The thick gray line shows the moved position of the SACCF and the thin black lines indicate the $2000-\mathrm{m}$ isobath.

on the western Antarctic Peninsula continental shelf are not transported to South Georgia. Drifters originating at sites on the outer part of the west Antarctic Peninsula continental shelf are transported only to within $600 \mathrm{~km}$ of South Georgia. Many of the drifters reach South Georgia from the south (Table 6). However, this is not beneficial in terms of krill transport, because these drifters originate in the open ocean, rather than in the krill spawning areas. For a February release the simulated drifter transport pattern (Fig. 10C) shows an even wider range of locations on the western Antarctic Peninsula shelf from which drifters cannot reach South Georgia. As a result, the entire southwestern part of the main krill spawning area does not provide krill to South Georgia. 


\section{Discussion}

\subsection{Model performance}

The simulated circulation fields reproduced features of the observed circulation in Drake Passage and in the Scotia Sea (cf. Fig. 2), especially the frontal structure of the flow and the mesoscale variability. The locations of the SACCF and the PF are moved about $100 \mathrm{~km}$ from the observed locations of the fronts in the WOCE A23 section in the eastern Scotia Sea. The location of the fronts in the HOPS model, as implemented in this study, is dependent on the bottom topography. The smoothing of the bottom topography makes the continental slopes about $10 \%$ gentler and smoothes topographic features, such as deep channels or sea mounts. This influences the location of the fronts. However, it has been shown that all fronts of the ACC meander, and lateral shifts of as much as $100 \mathrm{~km}$ over 10 days have been observed in the Drake Passage (Nowlin et al., 1977; Hofmann and Whitworth, 1985; Klinck, 1985; Nowlin and Klinck, 1986). In fact, during the WOCE A23 cruise a shift of the PF of more than $100 \mathrm{~km}$ in one week was observed (Heywood and King, 1996). Therefore, the simulated frontal locations are within the range of observed variability.

In addition, the paths of drifters around South Georgia (cf. Fig. 8) indicate that the location of the SACCF changes permanently from the initialized path looping to the west after reaching the north of South Georgia, to a path that turns east further south after 180 days of running time (cf. Fig. 2B). This is most likely due to the smoothed bottom topography in the model, in particular the North Georgia Rise to the north of South Georgia (cf. Fig. 1), that seems to be an important mechanism in steering the SACCF to the north of South Georgia before it turns eastward (Meredith et al., 2003). However, the general early eastward turn of the SACCF agrees with more recent studies that have not observed the SACCF in the previously reported location from Orsi et al. (1993). Trathan et al. (2000) did not find evidence of the SACCF, but found the Polar Front in this region and concluded the potential for great variability in this region. Observations and modeling studies in this area have shown the importance of eddyshedding off the SACCF (Thorpe et al., 2002; Meredith et al., 2003) and the high variability of the front itself.

\subsubsection{Hydrography}

Comparison of simulated vertical temperature and salinity distributions with observations showed that the vertical structure of the different water masses present in the Scotia Sea agreed in general but not in detail. The mismatches in the simulated and observed distributions are due to factors related to the implementation of the HOPS model. A primary factor is that the circulation model is initialized with the WOA 1998 climatological temperature and salinity fields (Antonov et al., 1998; Boyer et al., 1998), which is a smoothed representation of the hydrography in the study region. The data density used to construct this climatology is sparse in some parts of the study region and is also sparse over the entire region during the austral winter. Comparison of simulated vertical temperature and salinity fields with the climatology shows good agreement. This indicates that the simulated property fields are closely related to the initialization of the model and that discrepancies with observations are in part due to the insufficient representation of features in the climatology which then continue over time.

The model therefore is initialized with only an approximate representation of the observed hydrography that may not accurately represent the vertical water mass structure. In addition, the model relaxes to the climatological values at the model domain boundaries, which results in water flowing into or out of the model being set to climatological values. If there are any inconsistencies in the temperature and salinity values at the boundaries, then the water masses advected into the model are misrepresented. Therefore, data sets used for initialization of circulation models are of major importance and should be chosen carefully. In the study region, the availability of high-quality hydrographic data with good spatial and temporal resolution is lacking, which points to the need for further hydrographic observations and subsequent inclusion into available climatologies.

Further, no surface heating or cooling processes are included in this implementation of HOPS and, therefore, surface waters cannot undergo seasonal heating or cooling. Also, sea ice cover is not included in this model implementation even though large areas of the Weddell Sea and areas along the west Antarctic Peninsula may be covered with sea ice for some or all of the year. The dynamics associated with sea ice-ocean interactions are consequently missing. Thus, flow dynamics 
underneath the sea ice cover may therefore be altered and not calculated correctly in the simulated circulation fields. The lack of sufficient vertical mixing as a restorative mechanism may also be one reason why vertical temperature and salinity structures deteriorate over time. For a more accurate representation of the water masses, the inclusion of heat exchange with the atmosphere and sea ice dynamics is needed.

\subsubsection{Model drifters}

The comparison of simulated drifter trajectories with WOCE surface drifters showed that the surface drifters in the model were on average $38 \%$ slower than the WOCE drifters. Part of this disagreement arises from the time variability of the front locations and the probability that a simulated drifter is entrained in a front. Given the small model domain and the weak convergent flow at fronts, it is not expected that the simulated drifters would necessarily accumulate in fronts. The discrepancy between observed and simulated drifters also arises because the currents associated with the fronts in the simulated circulation fields are slower than observed.

Comparison of geostrophic flow speeds calculated from directly measured current velocity (Nowlin et al., 1977, Fig. 10) with the simulated current velocity obtained from the circulation simulations shows discrepancies of the same order. The vertical structure of the simulated currents agrees with the measured structure being fastest at the surface and decreasing with depth. The simulated current speeds are lower than observed with the error being $5 \%$ at the surface, $13 \%$ at $500 \mathrm{~m}$, and $11 \%$ at $1000 \mathrm{~m}$. However, the error bars of the directly measured velocities (Nowlin et al., 1977, Fig. 10) show a standard deviation of about $\pm 10 \mathrm{~cm} \mathrm{~s}^{-1}$ and the simulated current velocities are within the range of this deviation.

There are two main reasons for the noted differences in frontal speeds. First, the grid spacing of this model is $10 \mathrm{~km}$ and is therefore too coarse to define the sharp property gradients that are observed in these narrow features of $50 \mathrm{~km}$ width. As a result, the weaker density gradients produce smaller current velocities. Second, the horizontal dissipation of energy may be so strong that it is extracting kinetic energy, slowing the flow. The choice of the horizontal smoothing mechanism in HOPS, the Shapiro filter, used to dampen the twoto three-grid-interval waves reduces the steep frontal gradient and causes slower current speeds. A higher resolution model would counteract both problems. An additional contributing factor is the alteration of the deep, narrow channels. Smoothing not only changes the current flow, but can increase bottom skin friction and form drag that slow currents.

The noted discrepancies between the simulated circulation fields and observations indicate issues with the circulation dynamics included in the HOPS model and with the implementation of this model. However, the surface circulation, particularly through the Drake Passage and across the Scotia Sea, matches observations. The location of the fronts as well as the Weddell Sea and the Brazil Current and their associated transports match observations. In addition, mesoscale variability, an important component of the flow in this region, is represented in the simulated circulation.

\subsubsection{Flow dynamics around South Georgia}

General flow around South Georgia is mainly influenced by two of the circumpolar fronts, the PF and SACCF. The PF passes between Maurice Ewing Bank (cf. Fig. 1A) and South Georgia (Trathan et al., 1997) ensuring there are always polar waters around the Island and resulting in the Island being heavily glaciated $(>50 \%)$ (Brandon et al., 1999).

The local on-shelf waters around South Georgia are warmer and fresher than the off-shelf waters. This density difference gives rise to a baroclinic shelf break front (Brandon et al., 1999) that has been observed east and north of South Georgia (Brandon et al., 1999, 2000). Reasons for formation of warmer, fresher on-shelf water on the eastern shelf of South Georgia are complex due to South Georgia having two heavily glaciated mountain ranges running along its length with mountains up to a maximum of $2934 \mathrm{~m}$ and 12 peaks over $2000 \mathrm{~m}$ (Headland, 1984). While the mean climatological winds in the southwest Atlantic are from the west (Mayes, 1985) and reach South Georgia on the west coast, Richards and Tickell (1968) show a strong lee effect on the east side of the Island due to the mountains. The lee effect creates a microclimate and causes low humidities, a low amount of cloud formation, and as a consequence more sunshine and higher air temperatures (Brandon et al., 1999). This microclimate drives greater local melting and provides a strong local fresh-water runoff from South Georgia, which coupled with shelter from 
prevailing westerly winds, creates the observed warm fresh water pool.

This microclimate cannot be reproduced in the simulated circulation fields around South Georgia, because there is no freshwater input and the average wind used to force the model does not include local geographic effects. Therefore, no local shelf front can develop in the simulated circulation fields around South Georgia. In addition, the model resolution is too coarse $(10-\mathrm{km}$ grid spacing) to resolve shelf fronts. The across-shelf circulation is important in determining how particles reach the shelf waters that surround South Georgia. Thus, the specific dynamics of krill transport onto shelf waters around South Georgia cannot be investigated with the HOPS model as it was implemented in this study. A high-resolution model for the local South Georgia area, that includes the relevant environmental forcing and dynamics is needed.

\subsection{Krill origination areas and transport pathways}

The simulated transport patterns discussed in Section 4 can be grouped into five areas from which particles can reach South Georgia (Fig. 11). Of these five regions there are four regions from which krill can be transported to South Georgia in a period of

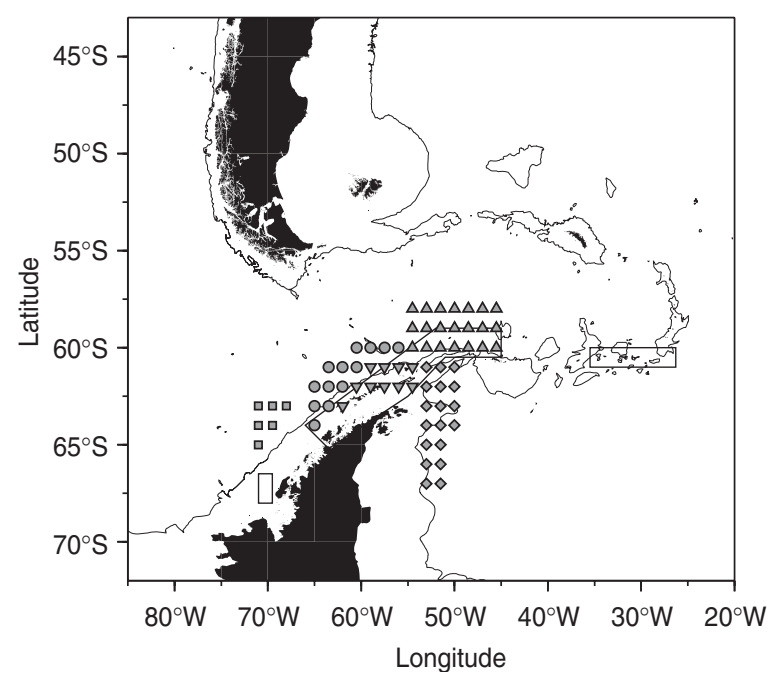

Fig. 11. Five areas around the Antarctic Peninsula that can potentially provide Antarctic krill to South Georgia. The areas are designated as: (1) western Antarctic Peninsula (•), (2)

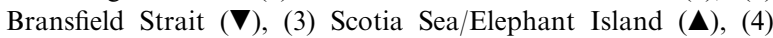
southwestern Antarctic Peninsula (ם), and (5) Weddell Sea $(\bullet)$. Rectangular boxes indicate areas of consistent krill spawning identified in Marr (1962). Thin lines show the 2000-m isobath.
10 months: the west Antarctic Peninsula, Bransfield Strait, the Elephant Island/Scotia Sea area, and the southwest Antarctic Peninsula (Fig. 11). These locations coincide with known krill spawning areas (Marr, 1962; Siegel, 1992). Simulated drifters originating in the Bransfield Strait region need about 263 days to reach South Georgia, while those originating along the west Antarctic Peninsula need about 211 days. The difference in transport times reflects the time needed to move out of the Bransfield Strait and become entrained in the SACCF. However, drifters originating near Elephant Island are transported to South Georgia on average in 168 days, the shortest transit time, while drifters originating at the southwest Antarctic Peninsula have the longest transport pathways and need on average 276 days.

Because of the slower speeds associated with the simulated circulation fields, the simulated krill transport times are best regarded as maximum time scenarios and indeed krill may be able to reach South Georgia faster than suggested by the simulations. A shorter transport time would benefit krill and result in higher numbers of krill surviving transport, as discussed in the following paper (Fach et al., 2006).

Krill originating near the continental shelf break of the Weddell Sea are transported to the Weddell Scotia Confluence in an average of 263 days and additional simulations showed that they are transported from there on to South Georgia (Fach, 2003). Total transport time is approximately 20 months. This potential transport of krill from the Weddell Sea to South Georgia agrees with studies that found cold water of Weddell Sea origin to the north and east of South Georgia (Hardy and Gunther, 1935; Deacon, 1977). This water has been suggested to be a main source of krill (Marr, 1962; Maslennikov and Solyankin, 1988). In addition, recorded tracks of giant icebergs showed that material of Weddell Sea origin can leave the Weddell Sea and can be transported along the east side of South Georgia, following the general path of the SACCF (Trathan et al., 1997). The drifter and krill growth simulations done in this study support Watkins et al. (1999) who suggest that krill from the Antarctic Peninsula and the Weddell Sea may reach South Georgia and may explain the different age structures of the local krill populations.

It has been suggested that krill may not be passively drifting organisms (Nicol, 2003a), but that environmental conditions and behavioral aspects of 
the krill life cycle may also influence their location. Krill behavior such as vertical migration is not included in this modeling study, but should be included in future studies, because it positions krill at levels with different flow speeds, which may influence overall transport pathways and times. Murphy et al. (2004b) have shown that such behavior can modify pathways of transport, but that current flows dominate the movement of krill in open ocean regions.

\subsection{Key processes controlling krill transport}

The ACC in the Drake Passage is known to shift its location during the year (Hofmann and Whitworth, 1985) or possibly over longer time scales (Klinck and Smith, 1993). A shift of the SACCF north, even of only $10 \mathrm{~km}$, leaves only a fraction of the large spawning area at the Antarctic Peninsula in the path of the SACCF, greatly reducing the possibility for transport of krill from the Antarctic Peninsula and the Weddell Sea to South Georgia. Thus, such a change in the location of the SACCF endangers the delivery of krill to South Georgia, especially from the main spawning area along the Western Antarctic Peninsula and in the Bransfield Strait. This may have a devastating effect on the krill population at South Georgia, which depends on the krill supply from further upstream. Such shifts in the SACCF may occur during the year (Hofmann and Whitworth, 1985; Hofmann and Klinck, 1998), indicating that the transport of krill to South Georgia is not necessarily continuous throughout the year, but may be episodic. This agrees with studies investigating variability of krill concentrations in the SACCF (Murphy et al., 2004b). If such a shift in the SACCF occurs about a month after spawning time, the effect may be that very few krill reach South Georgia and the population abundance is reduced. This type of variability may contribute to the strong fluctuations in krill abundance reported for waters around South Georgia (Heywood et al., 1985; Priddle et al., 1988).

The timing of the drifter release, which simulates different spawning times, shows that early release enhances the possibility of krill reaching South Georgia, especially from the main spawning area off the western Antarctic Peninsula. In Bransfield Strait, an area with a large krill population and active reproduction (Siegel, 1992), there are regions from which the circulation does not favor transport to South Georgia and this area increases with later spawning. The change in the size of this region is due to the wind conditions, which shift from westerly winds during early spring to northwesterly winds at the beginning of summer, creating less of an offshore component to the Ekman flux. Later spawning times also decrease chances for krill originating in the Weddell Sea to reach the vicinity of South Georgia. In contrast, later spawning increases the possibility for krill originating further north in Drake Passage to reach South Georgia. The effect of biological factors, such as food concentrations during transport and predation, on the survival rate of krill spawned at different times are explored further in Part II (Fach et al., 2006).

\section{Acknowledgments}

This research was supported by the US National Science Foundation, Office of Polar Programs Grant number OPP 9525806. The computer facilities and resources were provided by the Commonwealth Center for Coastal Physical Oceanography. We wish to thank Professor Alan Robinson, who generously allowed the use of the Harvard Ocean Prediction System and provided the model code. We are indebted to Patrick Haley and Pierre Lermusiaux for their help with HOPS over an extended period of time. We also thank three anonymous reviewers for valuable comments on an earlier version of the manuscript.

\section{References}

Antonov, J.I., Levitus, S., Boyer, T.B., Conkright, M.E., O'Brien, T.D., Stephens, C., 1998. World Ocean Atlas 1998. Volume 1: Temperature of the Atlantic Ocean. NOAA Atlas NESDIS 27, US Government Printing Office, Washington, DC, p. 166, CD-ROMs.

Atkinson, A., Whitehouse, M.J., Priddle, J., Cripps, G.C., Ward, P., Brandon, M.A., 2001. A productive, cold water pelagic ecosystem: a review of South Georgia, Antarctica. Marine Ecology Progress Series 216, 279-308.

Boyer, T.P., Levitus, S., Antonov, J.I., Conkright, M.E., O'Brien, T.D., Stephens, C., 1998. World Ocean Atlas 1998. Volume 4: Salinity of the Atlantic Ocean. NOAA Atlas NESDIS 30, US Government Printing Office, Washington, DC, p. 166, CDROMs.

Brandon, M.A., Murphy, E.J., Whitehouse, M.J., Trathan, P.N., Murray, A.W.A., Bone, D.G., Priddle, J., 1999. The shelf break front to the east of the sub-Antarctic island of South Georgia. Continental Shelf Research 19, 799-819. 
Brandon, M.A., Murphy, E.J., Trathan, P.N., Bone, D.G., 2000. Physical conditions to the northwest of the sub-Antarctic island of South Georgia. Journal of Geophysical Research 105, 23,983-23,996.

Bretherton, F.P., Davis, R.E., Fandry, C.B., 1976. A technique for objective analysis and design of oceanographic experiments applied to MODE-73. Deep Sea Research 23 (7), 559-582.

Brinton, E., 1985. The oceanic structure of the eastern Scotia Sea-III. Distributions of euphausiid species and their developmental stages in 1981 in relation to hydrography. Deep Sea Research 32 (10), 1153-1180.

Bryan, K., 1969. A numerical method for the study of the circulation of the world ocean. Journal of Computational Physics 4, 347-376.

Bryden, H.L., 1983. The Southern Ocean. In: Robinson, A.R. (Ed.), Eddies in Marine Science. Springer, Berlin, Heidelberg, New York, pp. 265-277.

Bryden, H.L., Pillsbury, R.D., 1977. Variability of deep flow in the Drake Passage from year-long measurements. Journal of Physical Oceanography 7, 803-810.

Cox, M.D., 1984. A primitive equation, three-dimensional model of the ocean. GFDL Ocean Group Technical Report 1, Geophysical Fluid Dynamics Laboratory, Princeton University, NJ, p. 147.

Croxall, J.P., McCann, T.S., Prince, P.A., Rothery, R., 1988. Reproductive performance of seabirds and seals at South Georgia and Signy Island, South Orkney Islands, 1976-1987: implications for Southern Ocean. In: Sahrhage, D. (Ed.), Antarctic Ocean and Resource Variability. Springer, Berlin, pp. 261-285.

Deacon, G.E.R., 1977. Seasonal and annual variations in water temperature and salinity near South Georgia 1925-1937. IOS Report no. 49, Institute of Oceanographic Sciences, Wormley, p. 30 .

Everson, I., 1984. Marine interactions. In: Laws, R.M. (Ed.), Antarctic Ecology, vol. 2. Academic Press, London, pp. 783-819.

Everson, I., Ward, P., 1980. Aspects of Scotia Sea zooplankton. In: Bonner, W.N., Berry, R.J. (Eds.), Ecology of the Antarctic. Academic Press, London, pp. 93-101.

Fach, B.A., 2003. Modeling studies of Antarctic krill (Euphausia superba) survival during transport across the Scotia Sea and Environs. Ph.D. Thesis, Old Dominion University, p. 215.

Fach, B.A., Hofmann, E.E., Murphy, E.J., 2006. Transport of Antarctic krill (Euphausia superba) across the Scotia Sea. Part II: krill growth and survival. Deep-Sea Research I, submitted for publication.

Fraser, F.C., 1936. On the development and distribution of the young stages of krill (Euphausia superba). Discovery Reports 14, pp. 1-192.

Gangopadhyay, A., Robinson, A.R., Arango, H.G., 1997. Circulation and dynamics of the western north Atlantic. Part I: multiscale feature models. Journal of Atmospheric and Oceanic Technology 16 (4), 1314-1332.

Gille, S.T., Kelly, K.A., 1996. Scales of spatial and temporal variability in the Southern Ocean. Journal of Geophysical Research 101, 8759-8773.

Gille, S.T., Stevens, D.P., Tokmakian, R.T., Heywood, K.J., 2001. Antarctic Circumpolar Current response to zonally averaged winds. Journal of Geophysical Research 106 (C2), 2743-2759.

Godlewska, M., 1996. Vertical migrations of krill (Euphausia superba Dana). Polish Archive of Hydrobiology 43 (1), 9-63.

Gordon, A.L., Molinelli, E., Baker, T., 1978. Large-scale relative dynamic topography of the Southern Ocean. Journal of Geophysical Research 83, 3023-3032.

Haney, R.L., 1991. On the pressure gradient force over steep topography in sigma coordinate models. Journal of Physical Oceanography 21, 610-619.

Hardy, A.C., Gunther, E.R., 1935. The plankton of the South Georgia whaling grounds and adjacent waters, 1926-1927. Discovery Reports 11, p. 456.

Headland, R.K., 1984. The Island of South Georgia. Cambridge University Press, Cambridge, UK, p. 293.

Heywood, K.J., King, B.A., 1996. WOCE section A23 cruise report, RRS James Clark Ross cruise 10, 20th March-6th May, 1995. UEA Cruise Report Series No. 1, University of East Anglia, Norwich, UK, p. 75.

Heywood, R.B., Everson, I., Priddle, J., 1985. The absence of krill from the South Georgia zone winter 1983. Deep Sea Research 32 (3), 369-378.

Hofmann, E.E., 1985. The large-scale horizontal structure of the Antarctic Circumpolar Current from FGGE drifters. Journal of Geophysical Research 90, 7087-7097.

Hofmann, E.E., Klinck, J.M., 1998. Thermohaline variability of the waters overlying the west Antarctic Peninsula continental shelf. In: Jacobs, S.S., Weiss, R.F. (Eds.), Ocean, Ice, and Atmosphere: Interactions at the Antarctic Continental Margin. Antarctic Research Series, vol. 75, pp. 67-81.

Hofmann, E.E., Whitworth III, T., 1985. A synoptic description of flow at Drake Passage from year-long measurements. Journal of Geophysical Research 90, $7177-7187$.

Hofmann, E.E., Klinck, J.M., Locarnini, R.A., Fach, B.A., Murphy, E.J., 1998. Krill transport in the Scotia Sea and environs. Antarctic Science 10 (4), 406-415.

Joyce, T.M., Patterson, S.L., 1977. Cyclonic ring formation in the Polar Front in the Drake Passage. Nature 265, 131-133.

Kalany, E., Kanamitsu, M., Kistler, R., Collins, W., Deaven, D., Gandin, L., Iredell, M., Saha, S., White, G., Woollen, J., Zhu, Y., Chelliah, M., Ebisuzaki, W., Higgins, W., Janowiak, J., Mo, K.C., Ropelewski, C., Wang, J., Leetmaa, A., Reynolds, R., Jenne, R., Joseph, D., 1996. The NCEP/NCAR 40-year reanalysis project. Bulletin of the American Meteorological Society 77 (3), 437-471.

Kalinowski, J., Witek, Z., 1980. Diurnal vertical distribution of krill aggregations in the West Antarctic. Polish Polar Research 1, 127-146.

Kils, U., 1982. Swimming behavior, swimming performance and energy balance of Antarctic krill Euphausia superba. In: ElSayed, S.Z. (Ed.), BIOMASS Scientific Series, vol. 3. Cambridge, England, p. 122.

Klinck, J.M., 1985. EOF analysis of central Drake Passage currents from DRAKE79. Journal of Physical Oceanography 15, 288-298.

Klinck, J.M., Smith, D.A., 1993. Effect of wind changes during the last glacial maximum on the circulation in the Southern Ocean. Paleoceanography 8 (4), 427-433. 
Knox, G.A., 1970. Antarctic marine ecosystems. In: Laws, R.M. (Ed.), Antarctic Ecology, vol. 2. Academic Press, London, pp. 69-109.

Lozano, C.J., Haley, P., Arango, H., Sloan, Q., Robinson, A.R., 1994. Harvard coastal/deep water primitive equation model. Harvard Ocean Model Reports 52, Reports in Meteorology and Oceanography, Harvard University, Cambridge, MA, pp. $1-15$.

Mackintosh, N.A., 1972. Life cycle of Antarctic krill in relation to ice and water conditions. Discovery Reports 36, p. 94.

Marr, J.W.S., 1962. The natural history and geography of the Antarctic krill Euphausia superba Dana. Discovery Reports 32, pp. 37-465.

Maslennikov, V.V., Solyankin, E.V., 1988. Patterns of fluctuations in hydrological conditions of the Antarctic and their effect on the distribution of Antarctic krill. In: Sarhage, D. (Ed.), Antarctic Ocean and Resources Variability. Springer, Berlin, pp. 209-213.

Mayes, P.R., 1985. Secular variations in cyclone frequency near the Drake Passage, southwest Atlantic. Journal of Geophysical Research 90 (D3), 5829-5839.

Meredith, M.P., Watkins, J.L., Murphy, E.J., Trathan, P.N., Ward, P., Bone, D.G., Thorpe, S.E., Grant, S.A., Ladkin, R.S., 2003. Southern ACC Front to the northeast of South Georgia: pathways, characteristics, and fluxes. Journal of Geophysical Research 108 (C5), 3162.

Messinger, F., 1982. On the convergence and error problems of the calculation of the pressure gradient force in a sigma coordinate model. Geophysical and Astrophysical Fluid Dynamics 19, 105-117.

Moore, J.K., Abbott, M.R., Richman, J.G., 1999. Location and dynamics of the Antarctic Polar Front from satellite sea surface temperature data. Journal of Geophysical Research 104, 3059-3073.

Murphy, E.J., Watkins, J.L., Reid, K., Trathan, P.N., Everson, I., Croxall, J.P., Priddle, J., Brandon, M.A., Brierley, A.S., Hofmann, E.E., 1998. Interannual variability of the South Georgia marine ecosystem: biological and physical sources of variation in the abundance of krill. Fisheries Oceanography 7 (3/4), 381-390.

Murphy, E.J., Thorpe, S.E., Watkins, J.L., Hewitt, R., 2004a. Modeling the krill transport pathways in the Scotia Sea: spatial and environmental connections generating the seasonal distribution of krill. Deep Sea Research II 51 (12-13), 1435-1456.

Murphy, E.J., Watkins, J.L., Meredith, M.P., Ward, P., Trathan, P.N., Thorpe, S.E., 2004b. Southern Antarctic Circumpolar Current Front to the northeast of South Georgia: horizontal advection of krill and its role in the ecosystem. Journal of Geophysical Research 109, C01029.

Nast, F., 1979. The vertical distribution of larval and adult krill (Euphausia superba Dana) on a time station south of Elephant Island, South Shetlands. Meeresforschung 27, $103-118$.

Nicol, S., 2003a. Krill and currents-physical and biological interactions influencing the distribution of Euphausia superba. Ocean and Polar Research 25 (4), 633-644.

Nicol, S., 2003b. Living krill, zooplankton and experimental investigations: a discourse on the role of krill and their experimental study in marine ecology. Marine and Freshwater Behavior and Physiology 36 (4), 191-205.
Niiler, P.P., Amos, A., Hu, J.-H., 1991. Water masses and 200-m relative geostrophic circulation in the western Bransfield Strait region. Deep Sea Research 38 (8/9), 943-959.

NOAA, 1988. Digital relief of the surface of the earth. Data Announcement 88-MGG-02. National Geophysical Data Center, Boulder, CO.

Nowlin Jr., W.D., Clifford, M., 1982. The kinematic and thermohaline zonation of the Antarctic Circumpolar Current at Drake Passage. Journal of Marine Science 40, 481-507.

Nowlin Jr., W.D., Klinck, J.M., 1986. The physics of the Antarctic Circumpolar Current. Reviews of Geophysics 24 (3), 469-491.

Nowlin Jr., Whitworth III, T., Pillsbury, R.D., 1977. Structure and transport of the Antarctic Circumpolar Current at Drake Passage from short-term measurements. Journal of Physical Oceanography 7 (6), 788-802.

Orsi, A.H., Nowlin Jr., W.D., Whitworth III, T., 1993. On the circulation and stratification of the Weddell Gyre. Deep Sea Research I 40, 169-203.

Orsi, A.H., Whitworth III, T., Nowlin Jr., W.D., 1995. On the meridional extent and fronts of the Antarctic Circumpolar Current. Deep Sea Research I 42, 641-673.

Peterson, R.G., Nowlin Jr., W.D., Whitworth III, T., 1982. Generation and evolution of a cyclonic ring at Drake Passage in early 1979. Journal of Geophysical Research 12 (7), 712-719.

Priddle, J., Croxall, J.P., Everson, I., Heywood, R.B., Murphy, E.J., Prince, P.A., Sear, C.B., 1988. Large-scale fluctuations in distribution and abundance of krill-a discussion of possible causes. In: Sahrhage, D. (Ed.), Antarctic Ocean and Resources Variability. Springer, Berlin, pp. 169-181.

Richards, P.A., Tickell, W.L.N., 1968. Comparison between the weather at Bird Island and Kind Edward Point, South Georgia. British Antarctic Survey Bulletin 15, 63-69.

Siegel, V., 1992. Assessment of the krill (Euphausia superba) spawning stock off the Antarctic Peninsula. Archiev für Fischereiwissenschaft 41 (2), 101-130.

Simmons, A.J., Burridge, D.M., 1981. An energy and angular momentum conserving finite difference scheme and hybrid vertical coordinates. Monthly Weather Review 109, 758-766.

Spall, M.A., 1988. Regional ocean modeling: primitive equation and quasigeostrophic studies. Harvard Open Ocean Model Reports 28, Reports in Meteorology and Oceanography, Harvard University, Cambridge, MA, p. 282.

Spall, M.A., Robinson, A.R., 1989. A new open ocean, hybrid coordinate primitive equation model. Mathematics and Computers in Simulation 31, 241-269.

Stein, M., 1992. Variability of local upwelling off the Antarctic Peninsula. Archiev für Fischereiwissenschaft 41, 131-158.

Thorpe, S.E., Heywood, K.J., Brandon, M.A., Stevens, D.P., 2002. Variability of the southern Antarctic Circumpolar Current front north of South Georgia. Journal of Marine Systems 37, 87-105.

Trathan, P.N., Brandon, M.A., Murphy, E.J., 1997. Characterization of the Antarctic Polar Frontal Zone to the north of South Georgia in summer 1994. Journal of Geophysical Research 102, 10,483-10,497.

Trathan, P.N., Brandon, M.A., Murphy, E.J., Thorpe, S.E., 2000. Transport and structure within the Antarctic Circumpolar 
Current to the north of South Georgia. Geophysical Research Letters 27 (12), 1727-1730.

Trenberth, K.E., Olson, J.G., Large, W.G., 1989. A global ocean wind stress climatology based on ECMWF analyses. Technical Report NCAR/TN-338+STR, National Center for Atmospheric Research, Boulder, CO, p. 93.

Watkins, J.L., Murray, A.W.A., Daly, H.I., 1999. Variation in the distribution of Antarctic krill Euphausia superba around South Georgia. Marine Ecology Progress Series 188, 149-160.
Whitworth III, T., Nowlin Jr., W.D., Worley, S.J., 1982. The net transport of the Antarctic Circumpolar Current through Drake Passage. Journal of Physical Oceanography 12, 960-971.

Witek, Z., Kalinowski, J., Grelowski, A., 1988. Formation of Antarctic krill concentrations in relation to hydrodynamic processes and social behavior. In: Sahrhage, D. (Ed.), Antarctic Ocean and Resources Variability. Springer, Berlin, pp. 237-244. 